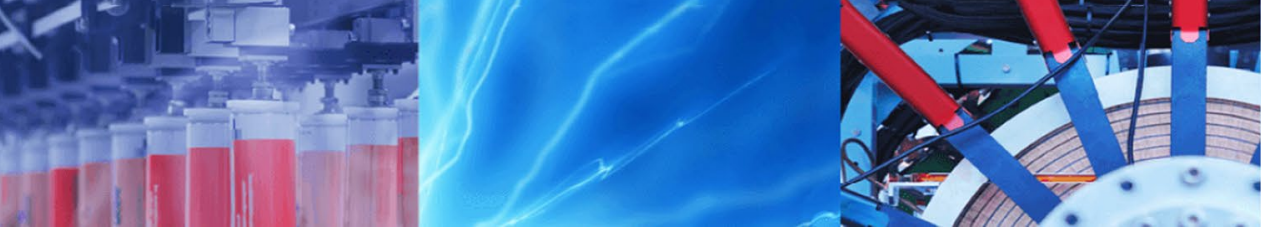

Research Article

\title{
Potent pharmacophoric aminothiazole derivatives as FabH inhibitors for antibacterial activity: in vitro and in silico approach
}

\author{
Nadine Uwabagira ${ }^{1} \cdot$ Balladka K. Sarojini $^{1,2} \cdot$ Madan K. Shankar $^{3} \cdot$ Ramesh S. Gani $^{2}$
}

(c) Springer Nature Switzerland AG 2019

\begin{abstract}
The present work reports the design, synthesis, characterization and antibacterial screening of novel aminothiazole derivatives as FabH inhibitor [ $\beta$-ketoacyl-ACP synthase (KAS)] which plays major role in bacterial cell wall construction. The compound $\mathbf{5 d}$ had crystallized in monoclinic, $P 21 / C$ space group which was determined by single-crystal X-ray crystallography. In vitro antibacterial activity studies were carried out on S. aureus (MCC 2043), E. faecalis (MTCC 2729), E. coli MTCC443 and C. violaceus (MCC 2216). Most of the compounds showed potent inhibition activity against Gram-negative bacteria than Gram-positive bacteria. Compound 5a showed the highest zone of inhibition of $16 \mathrm{~mm}$ and MIC value of $5.33 \mu \mathrm{M}$ which is comparable to that of the standard antibiotic, streptomycin. This result was ably complimented by in silico studies where compound 5a exhibited high affinity, strong binding energy and docking score of $6.214 \mathrm{kcal} \mathrm{mol}^{-1}$. The most potent compounds were nonhemolytic and nontoxic to mammalian cells.
\end{abstract}

Keywords Aminothiazole · Single crystal · The $\beta$-ketoacyl-ACP synthase (KAS) I - Antibacterial activity · Molecular docking $\cdot$ Molecular dynamic simulations

\section{Introduction}

Bacterial infections cause dangerous diseases and in many nations, a great number of mortality is seen especially in developing countries. These infectious diseases spread quickly and affect mostly the immunocompromised people, pregnant women, children, and older individuals [1]. Bacterial survival mostly depends on fatty acid biosynthesis. Three pathways are required for initiation of fatty acid biosynthesis; firstly $\beta$-ketoacyl-ACP synthase (KAS) III helps the condensation of acetyl-CoA and malonyl-CoA, secondly, there is a transfer of acetate moiety from acetylCoA to acetyl-ACP either by acetyl-CoA:ACP transacylase or $\beta$-ketoacyl-ACP synthase (KAS) III. Thirdly, there is a decarboxylation of malonyl-ACP by synthase I to form
acetyl-ACP which will be condensed with malonyl-ACP by synthase I [2]. The $\beta$-ketoacyl-ACP synthase (KAS) I is the only condensing enzyme required for the initiation of fatty acid biosynthesis [3]. Initially, this protein was inhibited by antibiotics such as thiolactomycin and cerulenin in bacteria and plants but in Saccharomyces cerevisiae and mammals there is appearance of antibiotic resistance [4]. In contrast, cerulenin specifically inhibits condensing enzyme which is $\beta$-ketoacyl thioester synthetase whereas thiolactomycin is able to inhibit the type II fatty acid synthetase [5] but inactive to type I. Extensive studies confirmed that excessive production of $\beta$-ketoacyl-ACP synthase (KAS) I contribute to thiolactomycin resistance to $E$. coli [6]. As some antibiotics have limitation of developing resistance

Electronic supplementary material The online version of this article (https://doi.org/10.1007/s42452-019-1298-2) contains supplementary material, which is available to authorized users.

Balladka K. Sarojini, bksaroj35@gmail.com | 'Biochemistry Division, Department of Chemistry, Mangalore University, Mangalagangothri, Karnataka 574199, India. ${ }^{2}$ Department of Industrial Chemistry, Mangalore University, Mangalagangothri, Karnataka 574199, India. ${ }^{3}$ PURSE Lab, Mangalore University, Mangalagangothri, Karnataka 574199, India.

SN Applied Sciences (2019) 1:1375 | https://doi.org/10.1007/s42452-019-1298-2

Received: 17 May 2019 / Accepted: 17 September 2019 / Published online: 11 October 2019 
or losing their potency, further research in this direction can be undertaken for optimal drug development.

Thiazole and its derivatives are known as active pharmaceutical ingredients in several drugs for their potential as anti-inflammatory $[7,8]$ anti-HIV, antiproliferative $[9,10]$, antibacterial and antifungal activity $[11,12]$. Furthermore, extensive research has been carried out on thiazole scaffolds for their anticancer [13] antimicrobial [14], antiallergy [15] and as central dopamine agonist agents [16]. The most prominent role played by thiazole compounds in general is found to be against multi-drug resistant tumor [17] and in the treatment of type- 2 diabetes [18].

There are many factors for bacteria to survive; among those factors fatty acid biosynthesis is essential as it is required for cell viability and growth [19]. Initiating fatty acid elongation cycles $[20,21]$ and involving in the feedback regulation of the biosynthetic pathway via product inhibition [22], make it a promising target for the design of novel antibacterial drugs.

In view of the above mentioned findings, in the present work, we report the design, synthesis, characterization and antibacterial activity of new series of aminothiazole derivatives against $E$. coli fatty acid biosynthesis (FabH). In vitro antibacterial activities were carried out on S. aureus (MCC 2043), E. faecalis (MTCC 2729), C. violaceus (MCC 2216) and E. coli (MTCC443). In addition, docking simulations were performed to position all synthesized compounds into the E. coli FabH active site to determine the probable binding conformation. The ten novel synthesized compounds were well characterized by ${ }^{1} \mathrm{H}$ NMR, ${ }^{13} \mathrm{C}$ NMR, FTIR, LCMS data and elemental analysis. The results of such studies are presented in this paper.

\section{Results and discussion}

\subsection{Chemistry}

The synthesis of new series of compounds is outlined in Scheme 1. The key intermediate, substituted phenylthiourea $\mathbf{2}$ was obtained from the reaction of ammonium thiocyanate on substituted aniline derivative 1 in concentrated $\mathrm{HCl}$ under reflux condition [23]. The substituted 4-phenacylbromides 4 were prepared by bromination of respective acetophenones $\mathbf{3}$ in chloroform solvent [24]. The new series of substituted phenyl thiazol-2-amine $\mathbf{5 a} \mathbf{a}-\mathbf{j}$ was synthesized by refluxing a mixture of substituted phenylthiourea derivatives $\mathbf{2}$ and 4-substituted phenacylbromides $\mathbf{4}$ in ethanol in the absence of any catalyst. The formation of the title compounds $\mathbf{5} \mathbf{a}-\mathbf{j}$ was confirmed by their analytical and spectral data.

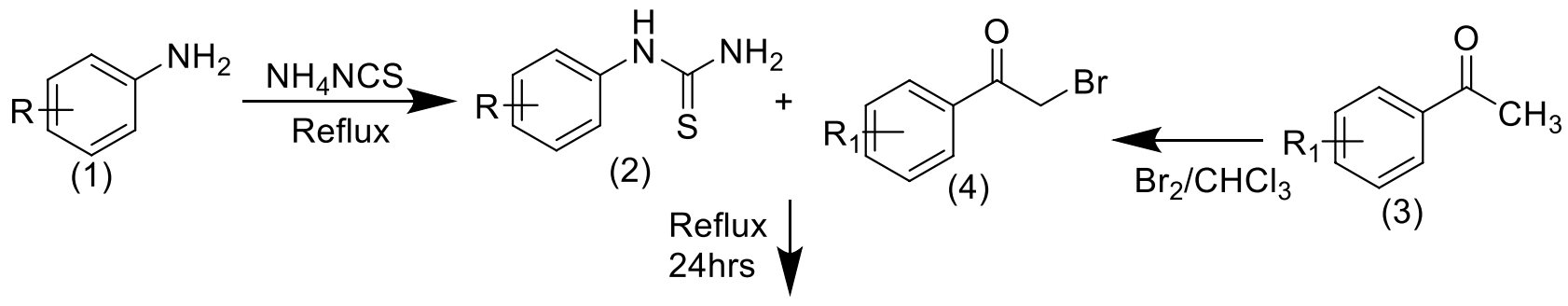

$\mathrm{R}$

$5 \mathbf{a}=3,4-\mathrm{Cl}$

$5 \mathrm{~b}=4-\mathrm{NO}_{2}$

$5 \mathrm{c}=3,4-\mathrm{Cl}$

$5 \mathrm{~d}=2,6-\mathrm{CH}_{3}$

$5 e=2-\mathrm{CH}_{3}-3-\mathrm{Cl}$

$5 \mathbf{f}=2-\mathrm{CH}_{3}-3-\mathrm{Cl}$

$5 \mathbf{g}=2-\mathrm{CH}_{3}-3-\mathrm{Cl}$

$5 \mathrm{~h}=2-\mathrm{CH}_{3}-4-\mathrm{F}$

$5 i=2,6-\mathrm{CH}_{3}$

$5 \mathrm{j}=2,6-\mathrm{CH}_{3}$
$\mathrm{R}_{1}$

$5 \mathrm{a}=4-\mathrm{NO}_{2}$

$5 b=4-F$

$5 \mathrm{c}=4-\mathrm{Cl}$

$5 \mathrm{~d}=4-\mathrm{Cl}$

$5 e=4-\mathrm{NO}_{2}$

$5 f=4-\mathrm{Cl}$

$5 \mathrm{~g}=4-\mathrm{OCH}_{3}$

$5 \mathrm{~h}=4-\mathrm{Cl}$

$5 \mathrm{i}=4-\mathrm{Cl}$

$5 \mathrm{j}=4-\mathrm{NO}_{2}$

Scheme 1 Synthesis of the title compounds (5a-j) 
The spectral details of representative compound $\mathbf{5 a}$ are as follows: in the IR spectrum of $\mathbf{5 a}$, an absorption band found at $3126 \mathrm{~cm}^{-1}$ was attributed to $\mathrm{NH}$ stretch. The absorption bands seen at $1494 \mathrm{~cm}^{-1}$ and $1616 \mathrm{~cm}^{-1}$ were due to the stretching frequency of $-\mathrm{C}=\mathrm{N}-$ and $-C=C-$ respectively. The presence of nitro group in the product was evidenced by two prominent absorption bands appearing at $1552 \mathrm{~cm}^{-1}$ and $1319 \mathrm{~cm}^{-1}$ for the antisymmetric and symmetric stretching frequencies of $\mathrm{NO}_{2}$ group. Likewise, an absorption band appeared at $725 \mathrm{~cm}^{-1}$ proved the presence of $-\mathrm{C}-\mathrm{Cl}$ stretching. On recording ${ }^{1} \mathrm{H}$ NMR spectrum, the formation of thiazole amine derivative $\mathbf{5 a}$ was supported by the presence of respective signals for the protons present in the molecule. A singlet seen at $\delta$ (ppm) 7.44 could be accounted for the thiazole ring proton. The two sets of ortho and meta protons of 4-nitro phenyl ring were seen as doublets centered at $8.25(J=8 \mathrm{~Hz})$ and $8.12(J=8 \mathrm{~Hz})$ respectively. A doublet appeared at $\delta(\mathrm{ppm}) 7.66(J=2.6 \mathrm{~Hz})$ and $7.62(J=2.7 \mathrm{~Hz})$ was accounted for one of ortho and meta protons of 3,4-dichlorophenyl ring respectively, and two singlets found at $\delta(\mathrm{ppm}) 7.47$ and $\delta(\mathrm{ppm}) 8.17$ were assigned to another ortho proton of 3,4-dichlorophenyl ring and thiazole proton respectively. The exocyclic $\mathrm{NH}$ proton appeared at $\delta(\mathrm{ppm}) 10.58$ as a singlet. This data confirmed the formation of the title compound $\mathbf{5 a}$.
Furthermore, it was supported by recording ${ }^{13} \mathrm{C} \mathrm{NMR}$ spectrum. The signals appeared in the spectrum could be assigned to the exact number of carbon atoms including magnetically equivalent ones. Molecular mass of $\mathbf{5 a}$ was determined by LCMS and was found to be $366.00(\mathrm{M}+\mathrm{H})^{+}$.

Similarly, the structure of all the synthesized molecules was determined by spectroscopic characterization and is given in experimental section.

\subsection{Single crystal X-ray crystallography of the compound $5 d$}

In order to determine the three dimensional structure of the title compounds, they were subjected to crystal growth by slow evaporation technique in suitable solvent. However, only the compound $\mathbf{5} \mathbf{d}$ was crystallized in a defractable form and the details of the crystal structure and data refinement are given in Table 1.

Molecular structure of the compound $\mathbf{5 d}$, showing the atomic numbering system. Displacement ellipsoids are drawn at the $50 \%$ probability. Dotted lines indicate intermolecular hydrogen bonds. The $\mathbf{5 d}$ molecule crystallized in monoclinic crystal system (space group P21/c) with unit cell parameters $a=14.0755(10), b=8.5068(3)$, $c=15.4086(10), \beta=108.390(7)$, volume $=1750.77(19)$ $\AA^{3}$ and $Z=4$. The ORTEP of $\mathbf{5} \mathbf{d}$ is shown in Fig. 1. The
Table 1 Crystal data and structure refinement details for compound 5d

\begin{tabular}{|c|c|}
\hline CCDC & 1845758 \\
\hline Empirical formula & $\mathrm{C}_{17} \mathrm{H}_{16} \mathrm{~N}_{2} \mathrm{ClSBr}$ \\
\hline Formula weight & 395.74 \\
\hline Temperature (K) & 293(2) \\
\hline Wavelength (Ka, Å) & 0.71075 \\
\hline Crystal system, space group & $\begin{array}{l}\text { monoclinic, } \\
P 21 / c\end{array}$ \\
\hline Unit cell dimensions $\left(\AA \AA^{\circ}\right)$ & $\begin{array}{l}a=14.0755(10) \\
b=8.5068(3) \\
c=15.4086(10) \\
\beta=108.390(7)\end{array}$ \\
\hline Volume $\AA^{3}$ & $1750.77(19)$ \\
\hline $\begin{array}{l}\mathrm{Z}, \\
\text { Calculated density }\left(\mathrm{Mg} \mathrm{m}^{-3}\right)\end{array}$ & $\begin{array}{l}4 \\
1.501\end{array}$ \\
\hline Absorption coefficient $\left(\mathrm{mm}^{-1}\right)$ & 2.617 \\
\hline$F_{(000)}$ & 800 \\
\hline Crystal size (mm) & $0.210 \times 0.230 \times 0.25$ \\
\hline Theta range for data collection $\left({ }^{\circ}\right)$ & 2.7 to 50.0 \\
\hline Limiting indices & $-16 \leq h \leq 16,-10 \leq k \leq 10,-18 \leq \mathrm{I} \leq 18$ \\
\hline Reflections collected/unique[R(int)] & $17,243 / 3087[0.042]$ \\
\hline Refinement method & Full-matrix least-squares on $F^{2}$ \\
\hline Data/restraints/parameters & $2592 / 0 / 201$ \\
\hline$R$ value & 0.0323 \\
\hline Goodness-of-fit on $F^{2}$ & 1.02 \\
\hline Largest diff. peak and hole (e. $\AA^{-3}$ ) & 0.30 and -0.26 \\
\hline
\end{tabular}




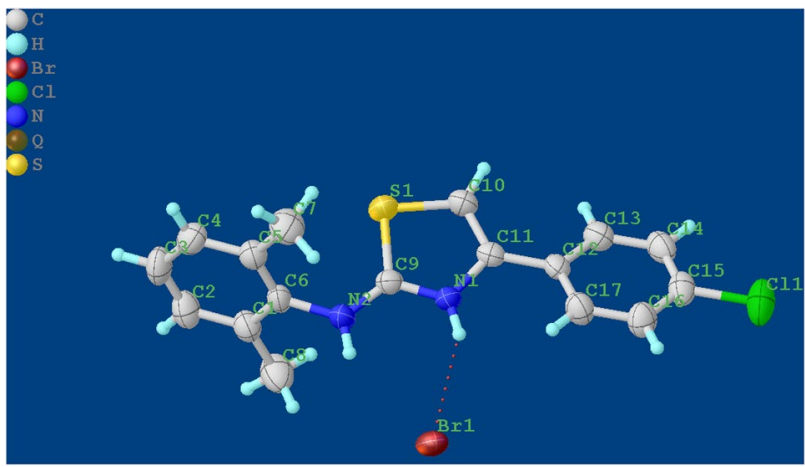

Fig. 1 The ORTEP of compound $\mathbf{5 d}$

thiazole ring (Cg1: $\mathrm{S} 1 / \mathrm{C} 9 / \mathrm{N} 1 / \mathrm{C} 11 / \mathrm{C} 10)$ makes a dihedral angle of $72.65(14)^{\circ}$ and $25.47(14)^{\circ}$ with methyl phenyl ring (Cg2:C1-C6) and chlorophenyl ring (Cg3:C12-C17), respectively. The dihedral angle between $\mathrm{Cg} 2$ and $\mathrm{Cg} 3$ is $82.24(14)^{\circ}$. Intramolecular hydrogen bonds $\mathrm{N} 1-\mathrm{H} 1$... Br1 and $\mathrm{N} 2-\mathrm{H} 2 \ldots \mathrm{Br} 2$ were observed. As one of the products in condensation was $\mathrm{HBr}$ (Scheme 1), the nitrogen of thiazole ring in compound $\mathbf{5 d}$, got protonated converting to quaternary nitrogen and the $\mathrm{Br}^{-}$existed as counter ion which is evident from Fig. 1.

In the crystal structure (Table 2 and Fig. 2), the molecules are stabilized through intermolecular interactions of the type C15-Cl1 ...Cg1, Cg2 ...Cg2 (3.77(17) $\AA$, slippage 1.301 , symmetry $=-x, 1-y,-z)$ and Cg3...Cg3 [(3.72(17) $\AA$, slippage 1.283 , symmetry $=1-x, 1-y, 1-z)$.

\section{Biological evaluations}

\subsection{Antibacterial studies}

All the tested compounds exhibited moderate activity against the four strains taken for evaluation (Fig. 3). Among tested compounds $\mathbf{5 a}, \mathbf{5 b}, \mathbf{5 c}, \mathbf{5 d}, \mathbf{5 e}$ and $\mathbf{5 i}$ have inhibited E. coli (MTCC443) effectively than other bacterial strains. The compounds $\mathbf{5 a}, \mathbf{5 e}, \mathbf{5 f}$ and $\mathbf{5 i}$ were found to be active against $C$. violaceum (MCC 2216) whereas $5 \mathbf{a}, \mathbf{5 e}, \mathbf{5 g}$ and 5h were effective against $E$. faecalis (MTCC 2729). The nitro and halo substitutions on either side of the phenyl rings affected the bactericidal property of the tested thiazole

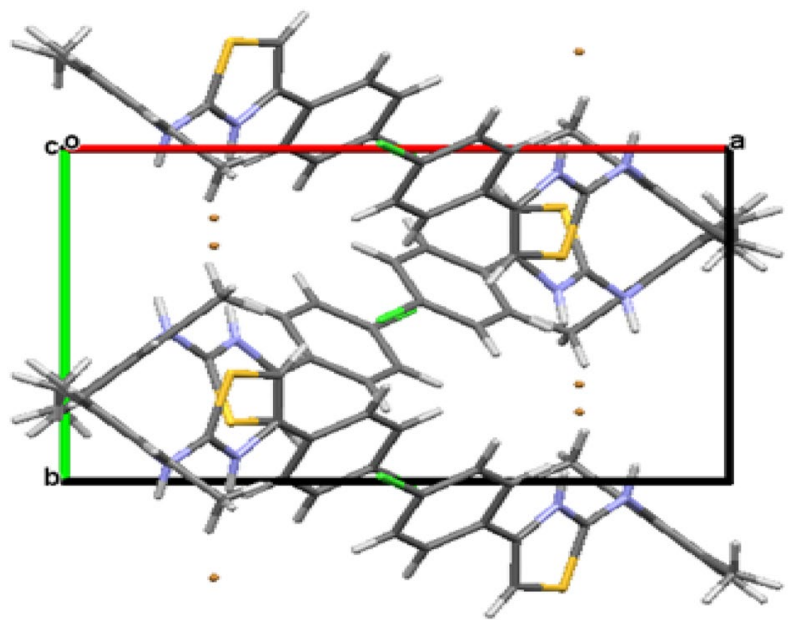

Fig. 2 Packing of the compounds: a view along c-axis

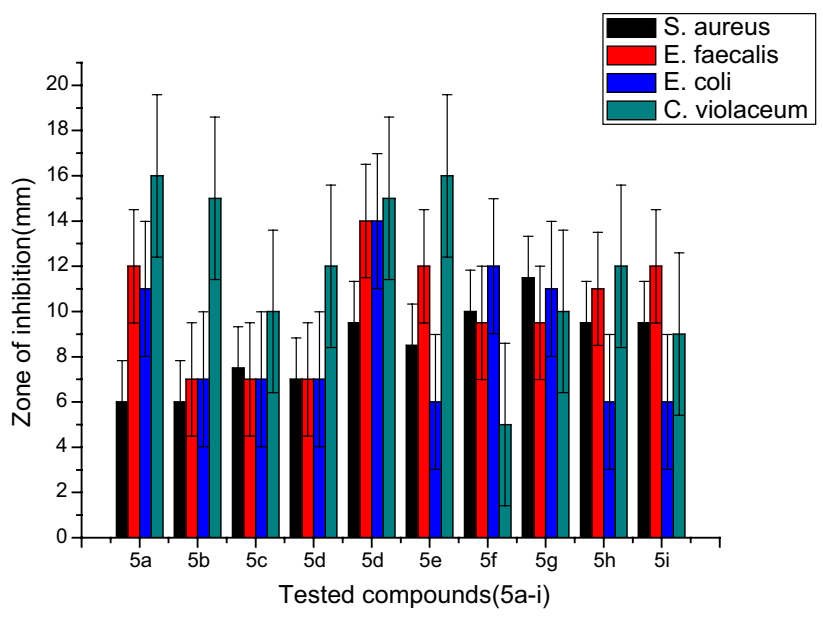

Fig. 3 Antibacterial activity by zone of inhibition $(\mathrm{mm})$

derivatives. But none of the title compounds were potent enough to arrest the growth of S. aureus (MCC 2043).

The compounds which exhibited notable zone of inhibition for the microbes were taken for the determination of MIC along with the standard streptomycin (Fig. 4). Among the active ones, the compound 5a emerged as most potent one against all the tested strains with MIC of $5.33 \mu \mathrm{M}$ which is comparable to standard drug (streptomycin).
Table 2 Intermolecular and intramolecular interactions

\begin{tabular}{llllll}
\hline $\mathrm{D}-\mathrm{H} / \mathrm{X} \ldots \mathrm{A} / \mathrm{Cg}$ & $\mathrm{D}-\mathrm{H} / \mathrm{X} \AA$ & $\mathrm{H} / \mathrm{X} \ldots \mathrm{A} / \mathrm{Cg} \AA$ & $\mathrm{D} \ldots \mathrm{A} / \mathrm{Cg} \AA$ & $\mathrm{D}-\mathrm{H} / \mathrm{X} \ldots \mathrm{A} / \mathrm{Cg}\left(^{\circ}\right)$ & Symmetry/centroid \\
\hline $\mathrm{N} 1-\mathrm{H} 1 \ldots \mathrm{Br} 1$ & 0.86 & 2.45 & $3.1765(17)$ & 143 & \\
$\mathrm{~N} 2-\mathrm{H} 2 \ldots \mathrm{Br} 2$ & 0.86 & 2.67 & $3.3619(18)$ & 139 & \\
$\mathrm{C} 15-\mathrm{Cl} 1 \ldots \mathrm{Cg} 1^{\mathrm{i}}$ & & $3.6232(15)$ & $4.100(3)$ & $92.95(11)$ & $1-\mathrm{X}, 1-\mathrm{Y}, 1-\mathrm{Z}$ \\
\hline
\end{tabular}




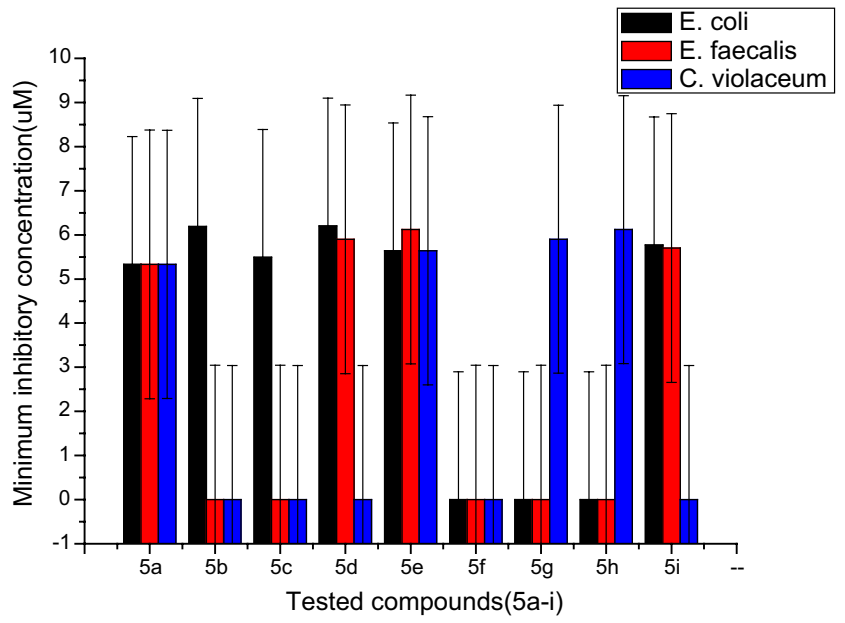

Fig. 4 Minimal inhibition concentration (MIC) in $\mu \mathrm{M}$

\subsection{Fatty acids inhibition activity}

In the positive standard which is E. coli MTCC443, assays were conducted to estimate different fatty acids levels and after the study, the fatty acid levels were found to be considerably low in the tested samples incubated along with $E$. coli. For saturated fatty acids, palmitic and stearic acids percentage for $\mathbf{5 a}, \mathbf{5 b}, \mathbf{5 c}$ and $\mathbf{5 e}$ were $(1.862$, $1.592) ;(1.446,1.740) ;(2.322,1.679)$ and $(3.504,2.486)$ respectively and the control (bacterial culture) was having three times greater the amount of fatty acid and was $(3.634,4.554)$. For monounsaturated fatty acids, only palmitoleic acid was 1.676, 1.502, 0.891 and $0.377 \%$ for $\mathbf{5 a}$, $\mathbf{5 b}, \mathbf{5 c}$ and $\mathbf{5 e}$ while the positive control was $2.158 \%$.

However, $(\omega-3)$ polyunsaturated fatty acids were not detected in the positive control and the samples treated with test compounds as well. Besides, $(\omega-6)$ polyunsaturated fatty acids (PUFA) were present and the percentage was almost zero indicating complete inhibition. For $\omega-6$ PUFA (Linoleic acids) percentage of inhibition for $\mathbf{5 a}, \mathbf{5} \mathbf{b}$, 5c and 5e was $0.512,0.614,2.779$ and $0.635 \%$ respectively and $7.121 \%$ for the control. The $\omega-6$ PUFA (Arachidonic acids) percentage for $\mathbf{5 a}, \mathbf{5} \mathbf{b}, \mathbf{5} \mathbf{c}$ and $\mathbf{5 e}$ was 0.512 , $0.604,0.601$ and $0.361 \%$ respectively and $5.251 \%$ for the control. The other fatty acids such as oleic, myristoleic, alpha linoleic, eicosapentaenoic, docosapentaenoic, docosahexaenoic, gamma linoleic and dihomo gamma linoleic acids were not found in the tested samples treated with the test samples. Among the tested compounds, compound $\mathbf{5 a}$ emerged as most potent one. The (Fig. 5) shows the results of $E$. coli fatty acid content after treating with the tested compounds. This result probably shows the ability of the tested compounds in reducing the bacterial (E. coli) fatty acid content.

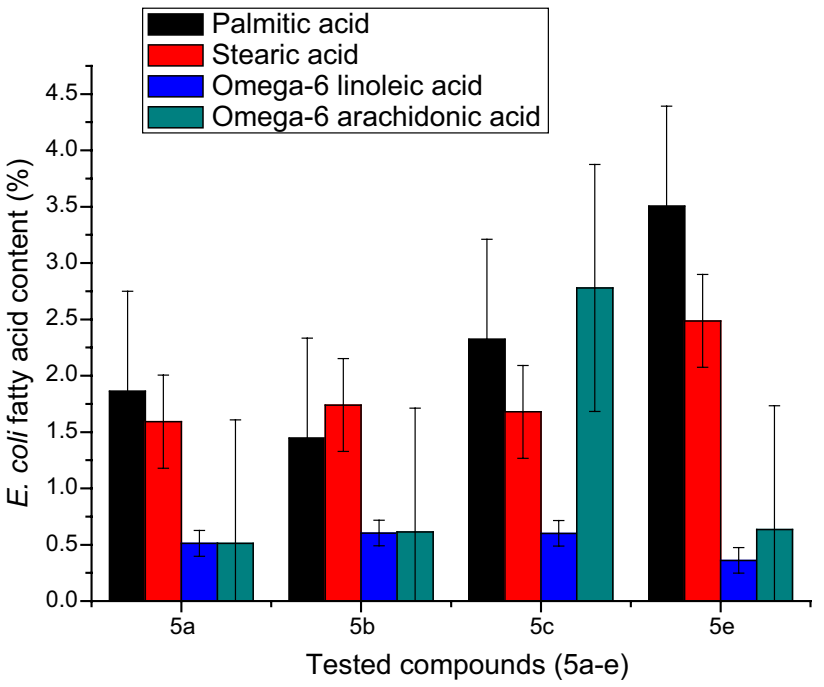

Fig. 5 E. coli fatty acid content (\%)

\subsection{Hemolysis assay}

The tested compounds were effective in inhibiting essential fatty acids in the microbial cell. It is assumed that similar array of fatty acids are also present in the human cells. So the evaluation of toxicity to human cells by the tested compounds was carried out by haemolysis assay. The percentage of haemolysis ranged between 0.88 and 12.27. The human blood toxicity activity of the tested compounds at minimum tested concentration of $12.5 \mu \mathrm{g} \mathrm{mL}^{-1}$ is in ascending order was as follows: $\mathbf{5 a}<\mathbf{5 c}<\mathbf{5 b}<\mathbf{5 e}<\mathbf{5} \mathbf{j}$. The maximum concentration of $100 \mu \mathrm{g} \mathrm{mL}^{-1}$ could do lysis only up to $12.27 \%$ for compound $\mathbf{5 j}$. The hemolysis assay showed that all tested compounds were less toxic on human blood especially the compound $\mathbf{5} \mathbf{a}$ and $\mathbf{5} \mathbf{b}$. All the tested compounds were found to possess minimum toxicity towards human blood cells as it was evidenced by the value given in Table 3 and Fig. 6 .

The Fig. 6 showed how the tested compounds are less toxic on human blood even at higher concentration $\left(100 \mu \mathrm{g} \mathrm{mL}^{-1}\right)$, the toxicity is less. Except the compound $\mathbf{5 j}$, the toxicity of the rest tested compounds is nearly indirectly proportional to the concentration of the sample and could be tolerable (5b, 5a, $\mathbf{5} \mathbf{c}$ and $\mathbf{5 e}$ respectively).

\subsection{Molecular docking studies}

The E. coli FabH (PDB ID: 5BNR) protein was docked into the active site of the model structure of FabH using Schrödinger Software, the ligands were prepared by ligprep, protein was prepared by protein preparation wizards, the Glide was generated by receptor grid generation for bioactive conformation searching then docking was 
Table 3 Percentage of hemolysis

\begin{tabular}{lll}
\hline Sample code & $\begin{array}{l}\text { Sample concentration } \\
\left(\mu \mathrm{mL}^{-1}\right)\end{array}$ & $\begin{array}{l}\text { Sample \% } \\
\text { haemolysis }\end{array}$ \\
\hline 5a & 100 & 4.59 \\
& 50 & 3.57 \\
& 25 & 3.37 \\
& $\mathbf{1 2 . 5}$ & $\mathbf{0 . 8 8}$ \\
$\mathbf{5 b}$ & 100 & 3.87 \\
& 50 & 3.60 \\
& 25 & 3.40 \\
& 12.5 & $\mathbf{2 . 1 8}$ \\
$\mathbf{5 c}$ & 100 & 8.26 \\
& 50 & 4.76 \\
& 25 & 2.82 \\
& 12.5 & $\mathbf{2 . 0 4}$ \\
$\mathbf{5 e}$ & 100 & 5.81 \\
& 50 & 5.00 \\
& 25 & 3.74 \\
& 12.5 & $\mathbf{2 . 1 9}$ \\
& 100 & 12.27 \\
$\mathbf{5 j}$ & 50 & 10.50 \\
& 25 & 4.04 \\
& 12.5 & $\mathbf{2 . 5 8}$ \\
\hline
\end{tabular}

The least concentration and hemolysis \% are in bold to show how the compound concentration is directly proportional to the $\%$ of hemolytic activity

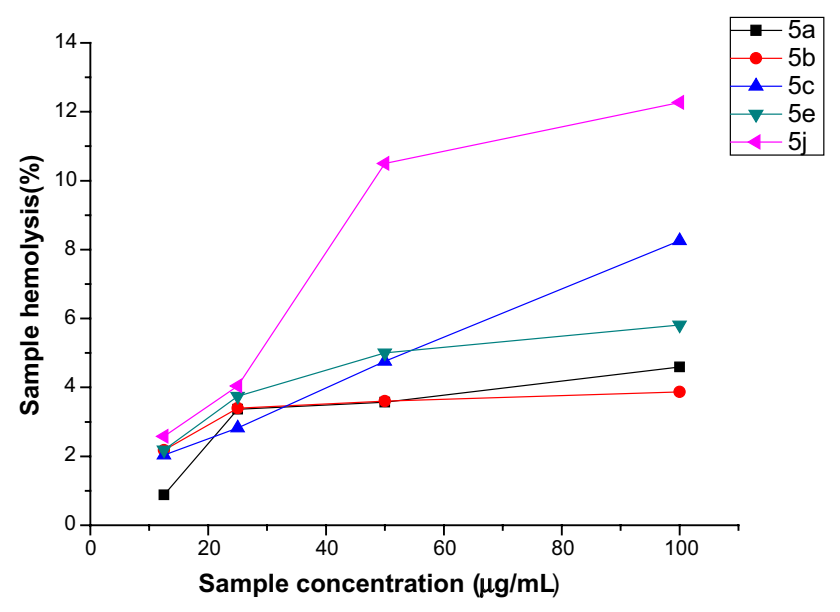

Fig. 6 Hemolysis essay results

done by extra precision (XP). The root mean square deviation (RMSD) was found to be 0.2949 which is reasonable as generally it should be less than 2 . The binding models as well as the ligand interaction diagrams of the potent compounds and E. coli FabH are depicted in the figures below.

Interaction of 5a: The E. coli FabH amino acids formed two strong hydrogen bonds (Asn ${ }^{274}$ with distance between the bond of $2.78 \AA$, angle of 112.7$)$ and Cys ${ }^{112}$ with distance between the bond of $2.19 \AA$, angle of $158.2 \AA$ ) and two halogen bonds ( $A s n^{210}$ with distance of $2.85 \AA$, angle of $127.3 \AA$ and dihedral of $39.6 \AA)$, ( $\mathrm{Arg}^{36}$ with distance of 2.52 , angle of 127.2 $\AA$, dihedral of $113.3 \AA$ ) with the compound 5a (Fig. 7).

Interaction of 5b: The E. coli FabH amino acids formed two strong hydrogen bonds ( $\mathrm{Asn}^{274}$ with distance of 2.28 , angle of $112.4 \AA$ ), Cys ${ }^{112}$ with distance of $2.23 \AA$, angle of $99.3 \AA$ ), one $\pi$-cation with $\operatorname{Arg}^{249}$ with distance of $4.68 \AA$, angle of $66.4 \AA$, dihedral of 159.3) and one aromatic hydrogen with $\mathrm{Gly}^{209}$ with distance of $2.46 \AA$, angle of $121.9 \AA$ and dihedral of $49 \AA$ (Fig. 8).

The interaction of 5c: The E. coli FabH amino acids formed five bonds: One $\pi$-cation with (Met ${ }^{1}$ with distance between the bond of $2.2 \AA$, angle of 94.2 , and dihedral of 53.6), three aromatic hydrogen bonds: (Asp ${ }^{123}$ with distance between the bond of $2.74 \AA$, angle of $109.7 \AA$ and dihedral of $158.7 \AA$ ), $11 e^{174}$ with distance of $2.46 \AA$, angle of $92.3 \AA$, dihedral of $121.6 \AA$ ) and (Met ${ }^{1}$ with distance of $0.82 \AA$, angle of $125.3 \AA$, dihedral of $179.1 \AA$ ) and one halogen bonds with Lys $^{127}$ with distance between the bond of $1.63 \AA$, angle of $143.5 \AA$ and dihedral of $30.4 \AA$ ) (Fig. 9).

The interaction of $5 \boldsymbol{e}$ The E. coli FabH amino acids formed one strong hydrogen bonds ( $\mathrm{Ser}^{169}$ with distance between the bonds was $2.17 \AA$, angle of $116.3 \AA$ ) ), two aromatic hydrogen bonds with $A \mathrm{sp}^{123}$ with distance between the bond was $2.72 \AA$, angle of $136.1 \AA$ ) and (Ile ${ }^{175}$ with distance between the bond of $2.21 \AA$, angle of $104.5 \AA$ ). Two halogen bonds with (Ile ${ }^{175}$ with distance of $3.27 \AA$, angle of $156.6 \AA$, dihedral of $24.9 \AA$ ) and (Lys ${ }^{127}$ with distance of $2.86 \AA$, angle of $116.0 \AA$, dihedral of $40.9 \AA$ ) (Fig. 10). The Table 4 showed Bonds, hydrophobic interactions and D-scores of the synthesized compounds.

\subsection{Molecular dynamic simulations of the compound $5 a$}

While docking, protein flexibility was not considered, in that occasion, molecular dynamic simulations were done with the Desmond program to confirm the mode of ligand binding as well as the stability of protein-ligand complex. The compound $\mathbf{5}$ a was showing the promising results and so was taken for molecular dynamic simulations (Figs. 11, 12, 13).

(RMSD) stands for the root mean square deviation and is the measurement of the atoms displaced and the last is directly proportional to the reference time.

The RMSD for frame $x$ is:

$$
R M S D_{x}=\sqrt{\frac{1}{N} \sum_{i=1}^{N}\left(r_{i}^{\prime}\left(t_{x}\right)\right)-\left(r_{i}\left(t_{r e f}\right)\right)^{2}}
$$


Fig. 7 Docking poses of the compound 5a with E. coli FabH (PDB Id-5BNR)
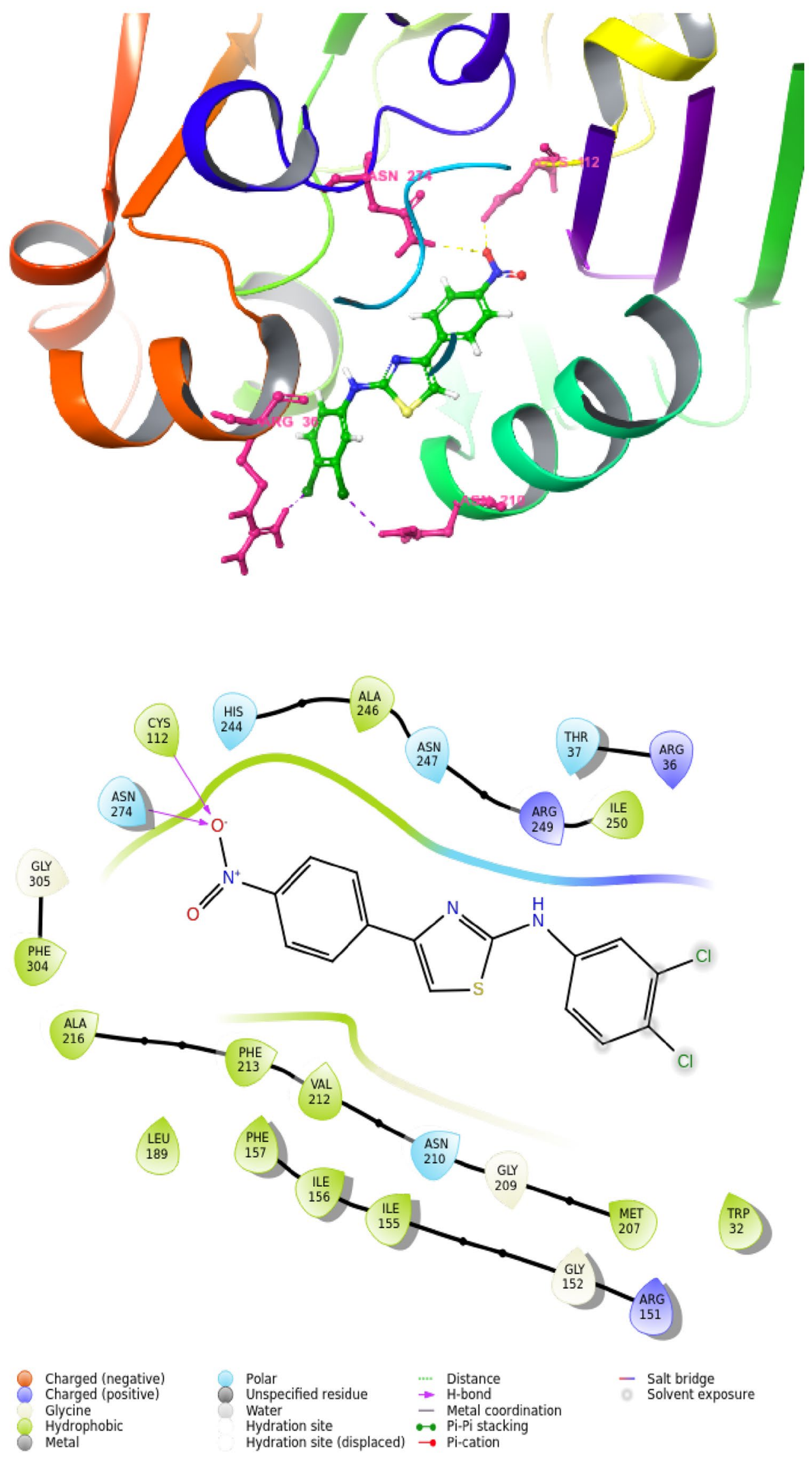

SN Applied Sciences 
Fig. 8 Docking pose of the compound $\mathbf{5 b}$ with E. coli FabH (PDB Id-5BNR)
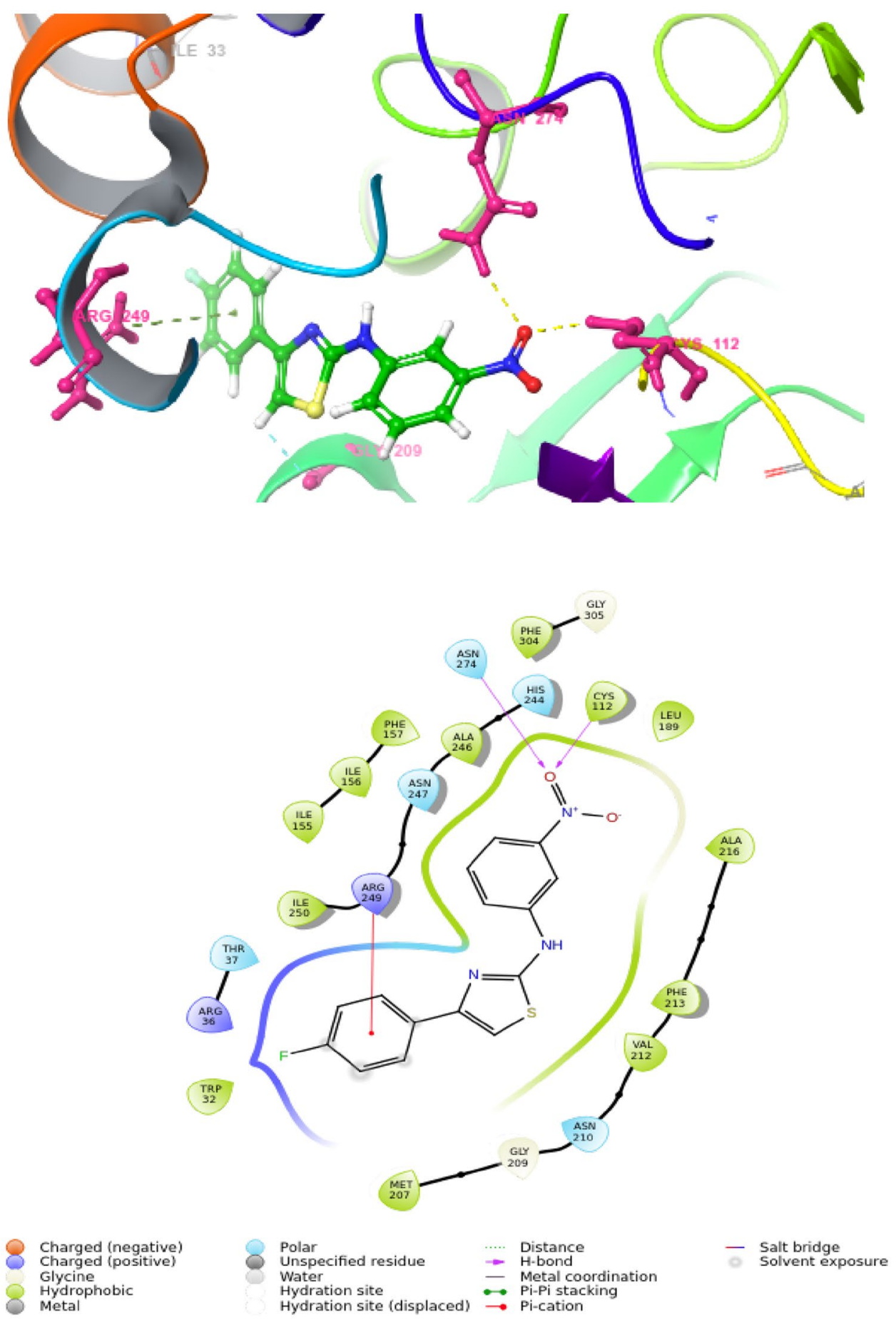
Fig. 9 Docking pose of the compound 5c with E. coli FabH (PDB Id-5BNR)

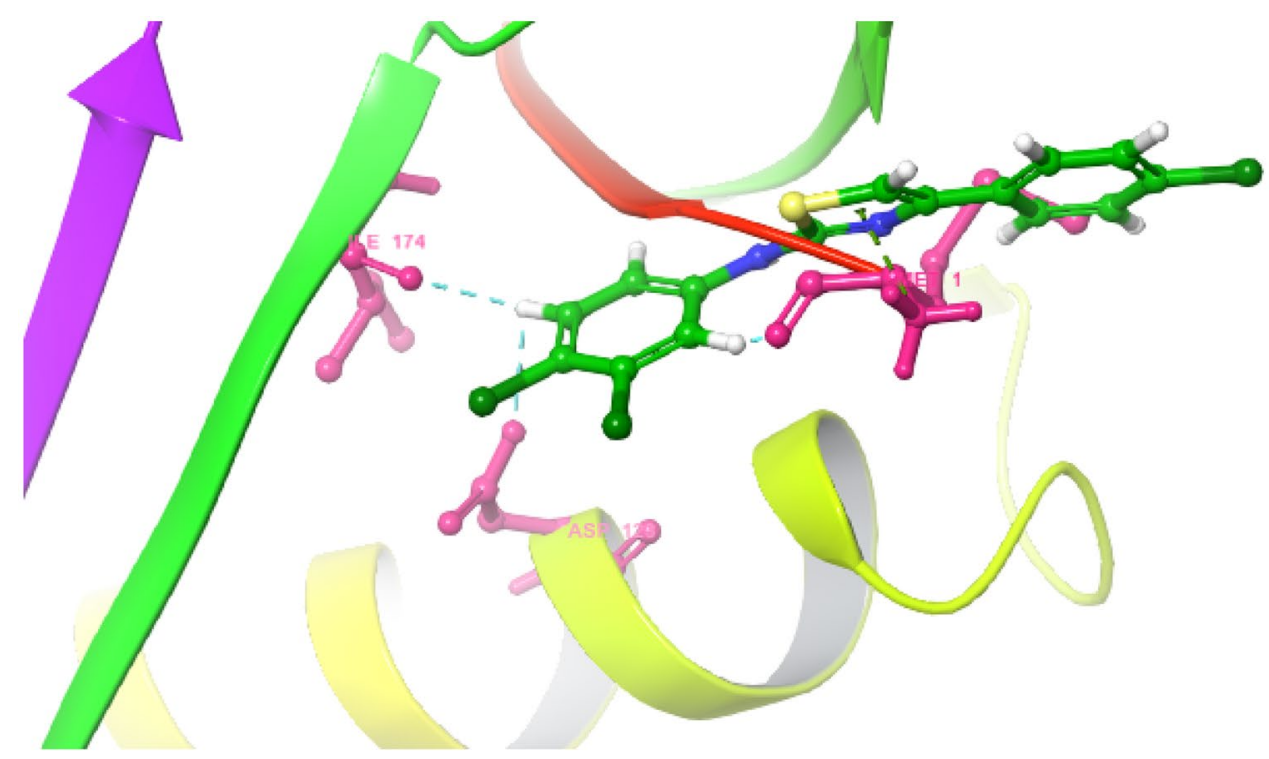

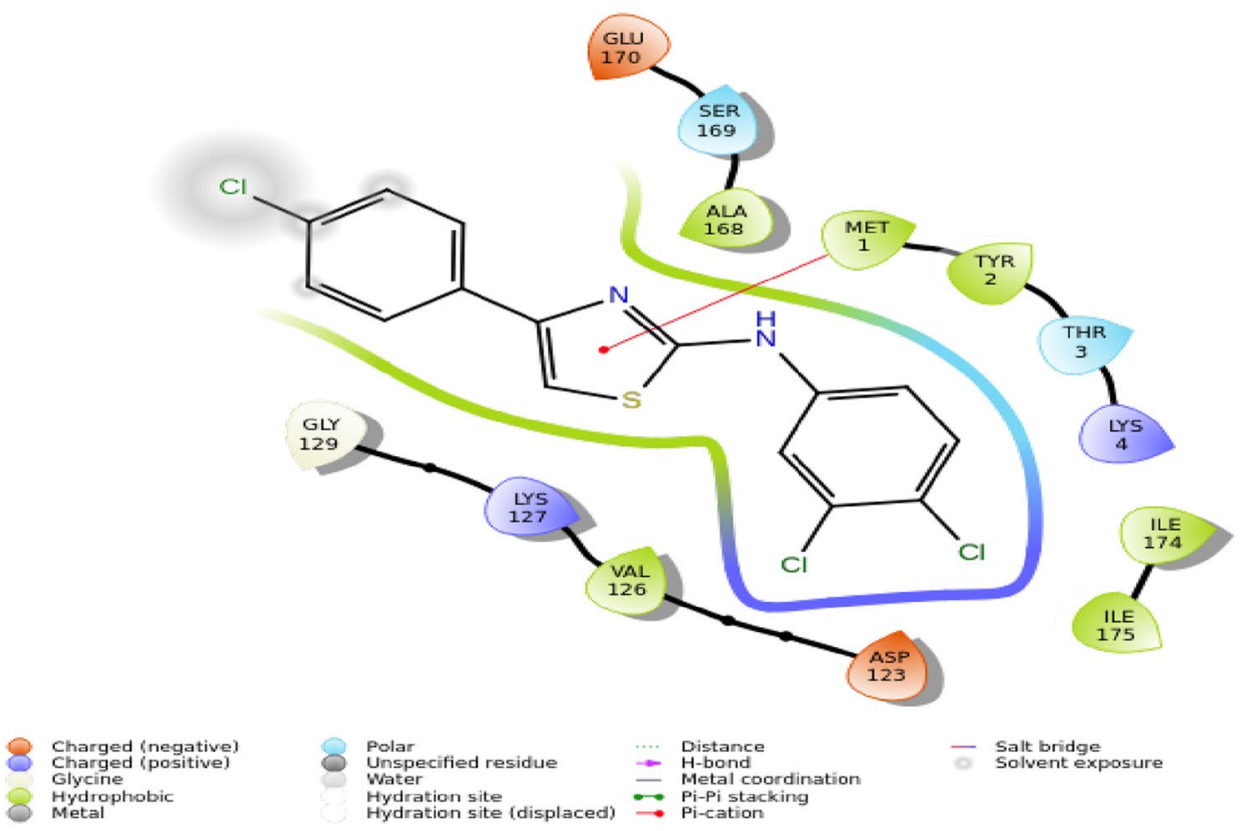

$\mathrm{N}$, the number of selected atoms; $t_{\text {ref }}$, the reference time (first frame, $t=0) ; r^{\prime}=$ the position of selected atom in the frame $x$ which is recorded at time $t_{x}$.

Protein RMSD found on the left Y-axis, RMSD is calculated on the basis of selected atom and its analysis gives the structural conformation.

Ligand RMSD found on right-Y-axis and showed the ligand stability.
The root mean square fluctuation (RMSF) characterizing local change with the protein chain showing the flexibility of each residue.

The RMSF for residue $i$ is:

$R M S F_{i}=\sqrt{\frac{1}{T} \sum_{t=1}^{T}\left\langle\left(r_{i}^{\prime}(t)\right)-\left(r_{i}\left(t_{r e f}\right)\right)^{2}\right\rangle}$ 
Fig. 10 Docking pose of the compound 5e with E. coli FabH (PDB Id-5BNR)
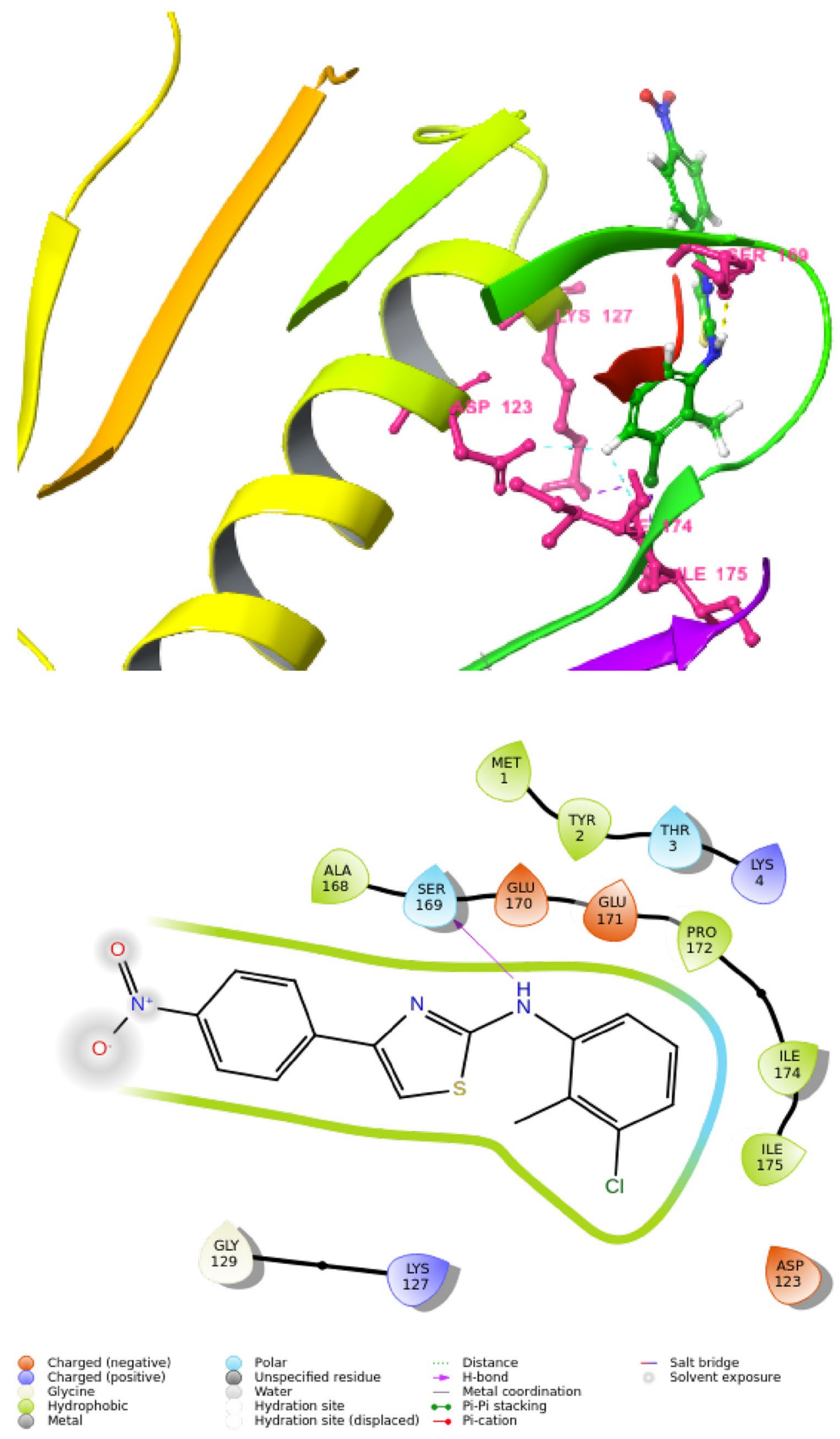
Table 4 Bonds, hydrophobic interactions and D-scores of the synthesized compounds

\begin{tabular}{|c|c|c|c|c|c|}
\hline & Compounds & $\pi-\pi$ or $\pi$-cation bonds & Aromatic, Halogen bonds & Hydrophobic interactions & $\begin{array}{l}\text { D-score } \\
\left(\mathrm{kcal} \mathrm{mol}^{-1}\right)\end{array}$ \\
\hline $5 a$ & $\Longrightarrow-\mathrm{NO}_{2}{ }^{\mathrm{Cys}^{112}}, \mathrm{Asn}^{247}$ & & $\operatorname{Arg}^{36}, \operatorname{Asn}^{210}$ & $\begin{array}{l}\mathrm{Ile}^{156,250}, \mathrm{Ala}^{221,216}, \mathrm{Phe}^{304,} \\
{ }_{392}, \mathrm{Val}^{217,304}\end{array}$ & -6.214 \\
\hline $5 \mathbf{b}$ & $\mathrm{Asn}^{274}, \mathrm{Cys}^{112}$ & $\operatorname{Arg}^{249}$ & Gly $^{209}$ & $\begin{array}{l}\mathrm{Ile}^{250}, \mathrm{Ala}^{246,208}, \mathrm{Phe}^{213} \\
304, \mathrm{Met}^{207}, \mathrm{Val}^{212} \\
\text { Gly }^{152,209}, \text { Leu }^{248}, \operatorname{Trp}^{32}\end{array}$ & -5.774 \\
\hline $5 c$ & & Met $^{1}$ & $\mathrm{Ile}^{174}$, Asp $^{123}$, Lys $^{127}$, Met $^{1}$ & $\mathrm{Ile}^{174}, \mathrm{Ala}^{167,168}$, Met $^{1}$ & -5.838 \\
\hline $5 d$ & $\mathrm{Ala}^{246}$ & & Gly $^{152}$ & $\begin{array}{l}\text { Ile }{ }^{155,156,250}, \text { Phe }^{157}, \\
\text { Phe }^{213,304}{ }^{4} \operatorname{Trp}^{32}, \text { Ala }^{143}, \\
\text { Met }^{207}, \text { Leu }^{142}\end{array}$ & -6.648 \\
\hline $5 e$ & $\operatorname{Ser}^{169}$ & & $\mathrm{Ile}^{175}$, Asp $^{123}$, Lys $^{127}$ & $\mathrm{Ile}^{5,174}$, Met $^{1}$, Pro $^{172}$, Gly ${ }^{173}$ & -5.862 \\
\hline $5 f$ & & $\operatorname{Arg}^{249}$ & Cys $^{112}$, Gly $^{209}$ & $\begin{array}{l}\text { Val }^{212,215}, \text { Phe }^{157}, \text { Phe }^{213} \\
304, \text { Gly }^{209}, \text { Ile }^{155,156} \\
\text { Val }^{215,217}, \text { Ala }^{216}\end{array}$ & -6.455 \\
\hline $5 g$ & & $\operatorname{Arg}^{249}$ & Gly $^{209}$, Cys $^{112}$ & $\begin{array}{l}\operatorname{Trp}^{32}, \mathrm{Phe}^{157,213,304,308} \\
\mathrm{Gly}^{209,305}, \mathrm{Ile}^{156}, \mathrm{Ala}^{216} \\
\text { Val }^{212,215}\end{array}$ & -6.413 \\
\hline $5 \mathrm{~h}$ & $\underset{\mathrm{Cl}}{\mathrm{Ala}}{ }^{246}, \mathrm{Asn}^{247}$ & $\operatorname{Arg}^{249}, \mathrm{His}^{244}$ & $\operatorname{Arg}^{36}$, Gly $^{209}$ & $\begin{array}{l}\operatorname{Trp}^{32,304,310}, \mathrm{Phe}^{157,213} \\
\operatorname{Val}^{215,217}, \mathrm{Gly}^{152}, \mathrm{Gly}^{305} \\
\mathrm{Ala}^{216}, \mathrm{Il}^{156,250}\end{array}$ & -6.226 \\
\hline $5 \mathbf{i}$ & $\mathrm{Ala}^{246}$ & $\operatorname{Arg}^{249}$ & Gly $^{209}$ & $\begin{array}{l}\mathrm{Gly}^{305}, \mathrm{Ala}^{216}, \mathrm{Phe}^{157,213} \\
304, \mathrm{Val}^{212,215,217}, \operatorname{Trp}^{32} \\
\mathrm{Ile}^{155,156}\end{array}$ & -6.407 \\
\hline $5 \mathbf{j}$ & $\mathrm{Ala}^{246}, \mathrm{Arg}^{36}$ & $\operatorname{Arg}^{249}$ & $\mathrm{Thr}^{153}$ & $\begin{array}{l}\text { Ile }{ }^{155,250}, \text { Phe }^{157,213,304} \\
\text { Gly }^{152}, \text { Leu }^{142}, \operatorname{Trp}^{32}\end{array}$ & -6.642 \\
\hline
\end{tabular}

D-score is in bold to emphasize the binding affinity of the ligand and the protein

Here, $T$ is the trajectory time over which the RMSF is calculated, $t_{\text {ref }}$ is the reference time; $r^{\prime}$ is the position of the atom $i$ at time $t$ after superposition on the reference frame.

Throughout this simulation, the protein secondary structure elements (SSE) were checked. Alpha-helices (red colour) and beta-strands (blue colour) are observed. Each and every trajectory frame of SSE is summarized in the Fig. 14. The plot below explains deeply the residues index distribution in the structure of the protein Fig. 15.

The Ligand Root Mean Square Fluctuation (L-RMSF) is useful for characterizing local change with the ligand chain showing the flexibility of each residue (Figs. 16, 17, 18).

The RMSF for atom $i$ is:

$R M S F_{i}=\sqrt{\frac{1}{T} \sum_{t=1}^{T}\left(r_{i}^{\prime}(t)\right)-\left(r_{i}\left(t_{r e f}\right)\right)^{2}}$

Here, $\mathrm{t}$ is the trajectory time over which the RMSF is calculated, $t_{r e f}$ is the reference time; $r$ is the position of the atom $i$ at time $t$ after superposition on the reference frame. 
Protein Information

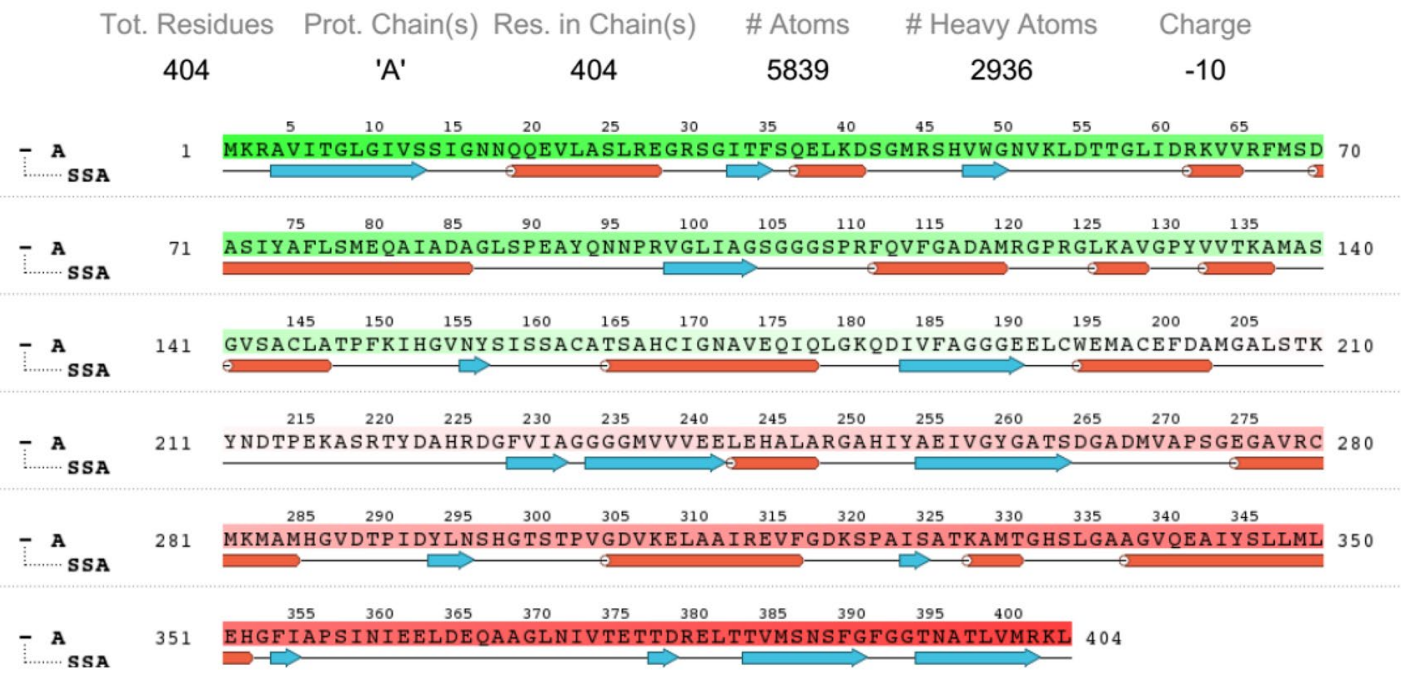

Fig. 11 Protein information

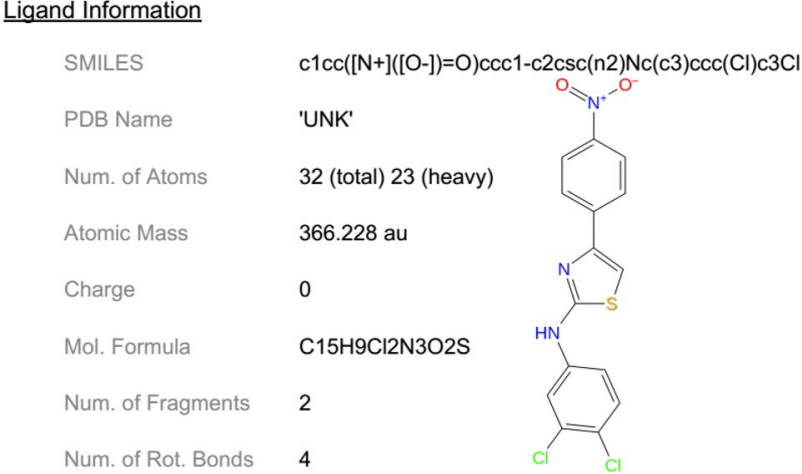

Fig. 12 Ligand information
The ligand RMSF gives the intuitions on how the ligand and protein interact as well as their entropic role and binding event. In the Fig. 19, with respect to the protein, the ligand fluctuations are shown in the 'Fit Ligand on the Protein line.

Protein-ligand interactions were checked throughout the simulation and were having four categories such as hydrogen bonds, hydrophobic, ionic and water bridges. Simulation Interaction Diagram' panel below showed interactions fractions over the course of the trajectory, for example, a value of 0.7 suggests that $70 \%$ of the simulation time and the specific interaction was maintained (Figs. 20, 21).

Fig. 13 Protein-ligand RMSD

Protein-Ligand RMSD

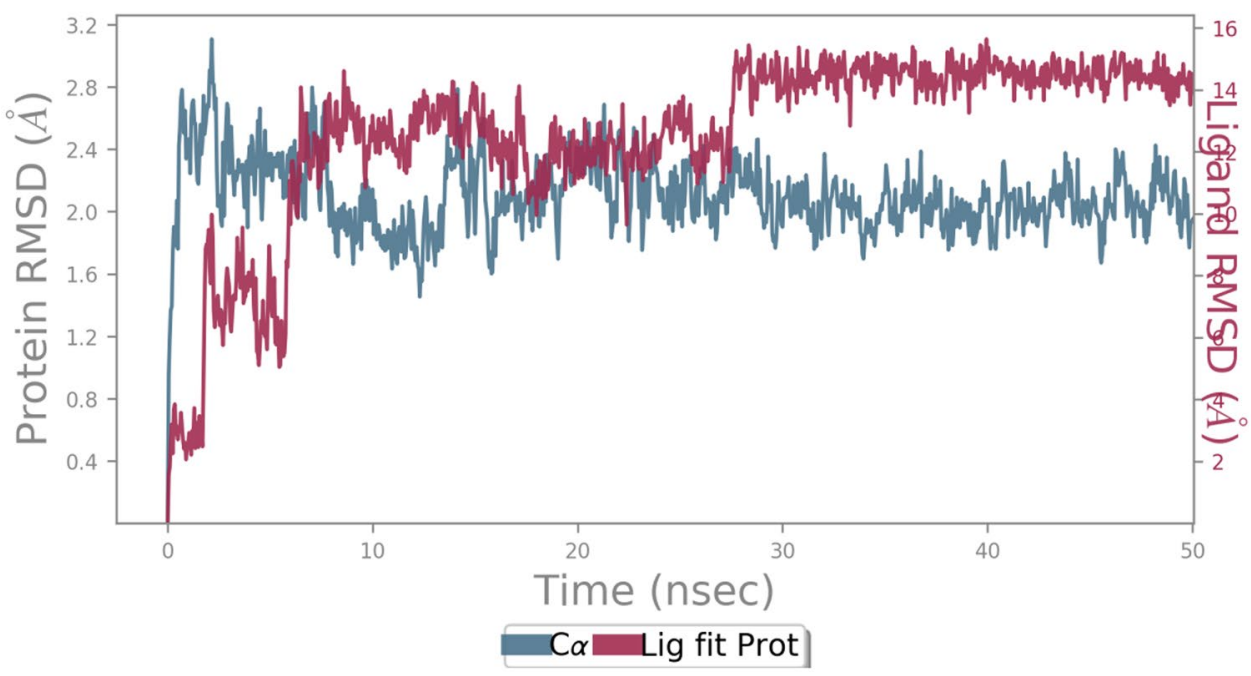

SN Applied Sciences 
Fig. 15 Protein secondary structure

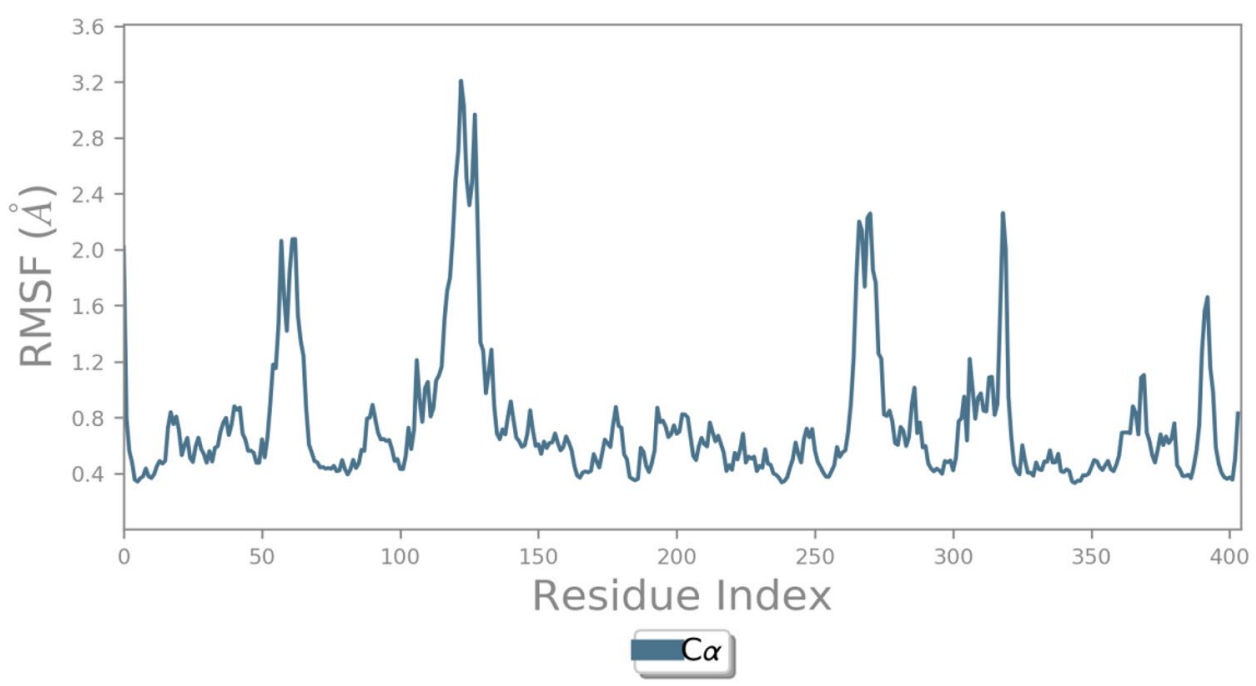

Protein Secondary Structure

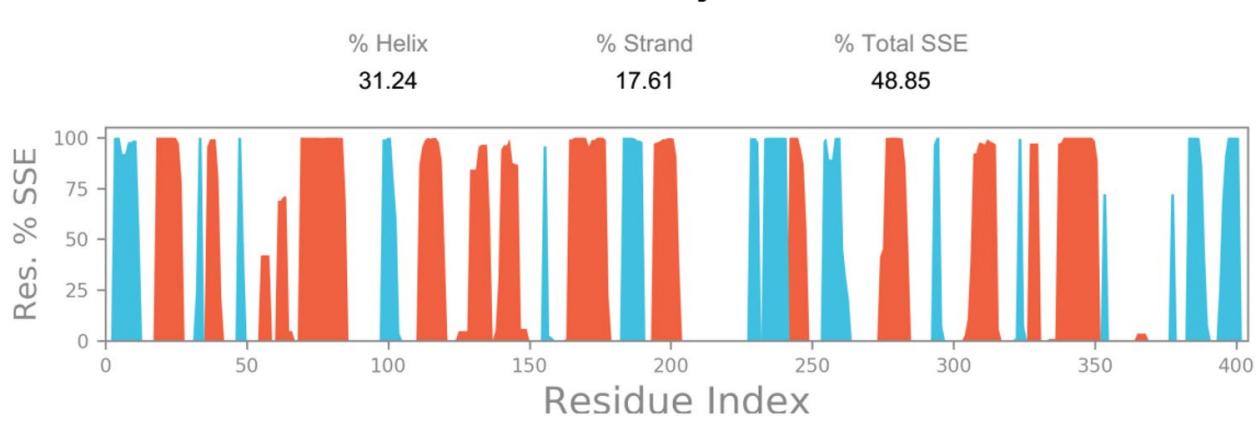

Hydrogen bonds complex stability is the must and this is provided by hydrogen bonds. The affinity of the ligand on the protein is shown by hydrogen bonds. However, hydrogen-binding property is very important in drug design because of its specificity in drug metabolization and adsorption.

Hydrophobic contacts these complain $\pi-$ cation, $\pi-\pi$, and other no specific interactions.

Ionic interactions these characterize between two oppositely charged atoms.

Water bridges are hydrogen-bonded protein-ligand interactions mediated by a water molecule.

The Fig. 22 showed ligand-protein contact and indicated more than $30 \%$ of interactions meaning that the amino acid residues can $\mathrm{H}$-bond with $\mathrm{H}$-bond acceptor of the ligand. This trajectory was done through $50 \mathrm{nsec}$ (Figs. 23, 24).
Ligand RMSD Here, we see the Root mean square deviation of the ligand with respect to the reference conformation.

Radius of gyration (rGyr) it helps in exhibition of conformational stability and the smaller the value of the radius of gyration, the better folding of the molecule. This stability is maintained by the constancy of the said radius.

Intramolecular hydrogen bonds (intraHB) Number of internal hydrogen bonds (HB) within a ligand molecule, here they were not detected.

Molecular surface area (MolSA) Molecular surface calculation with $1.4 \AA$ probe radius which is value of equivalent to a van der Waals surface.

Solvent accessible surface area (SASA) Surface area of a molecule accessible by a water molecule.

Polar surface area (PSA) Solvent accessible surface area in a molecule contributed only by oxygen and nitrogen atoms. 
Fig. 16 The residues index distribution in the structure of the protein

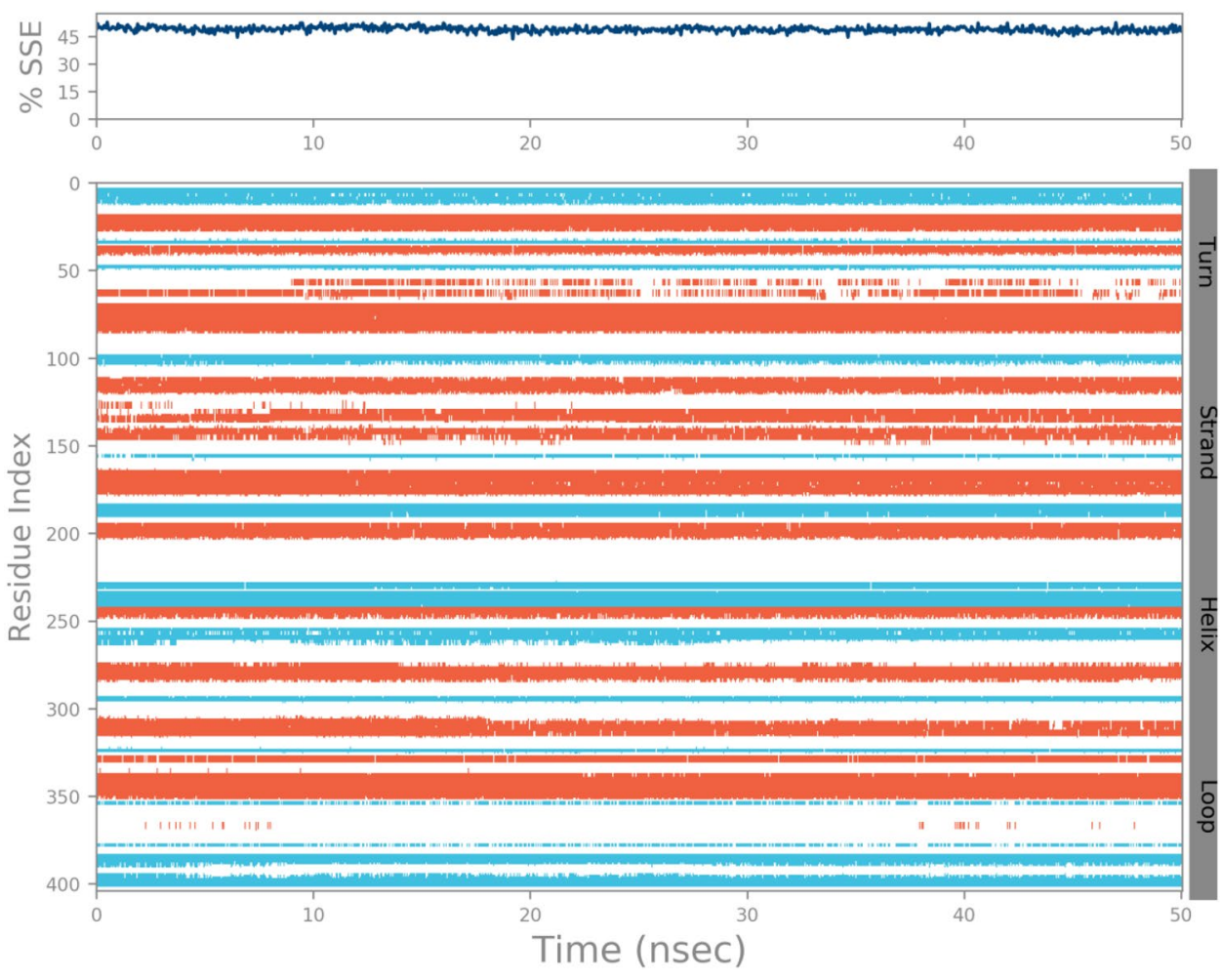

Generally, Cys-Hie-Asn triad tunnel is the catalytic active site of $\mathrm{FabH}$. Since this triad is conserved in bacteria and plays a significant role in chain elongation regulation and substrate binding, any interaction between the said triad and substrate revealed an important role in substrate-binding [25]. The potency of the compounds is explained by their interactions with $\mathrm{Cys}^{112}, \mathrm{Hie}^{244}$ or $\mathrm{Asn}^{247}$ residues of the proteins $\mathrm{FabH}$. Studies on E. coli $\mathrm{FabH}$ confirmed that $\mathrm{Hie}^{244}$ and $\mathrm{Asn}^{247}$ are required for decarboxylation and Cys ${ }^{112}$ is essential in transacylation [26]. Thiolactomycin has shown its efficacy to inhibit fatty acid synthase system but not acetyl-CoA carboxylase. Since some of our compounds were having interactions with $\mathrm{Hie}^{244}$ or $\mathrm{Asn}^{247}$; this might explain their potency on acetyl-CoA carboxylase as they were required in decarboxylation of the mentioned protein. In addition to this, all the synthesized compounds had many good interactions with hydrophobic amino acids. The docking results with the synthesized compounds revealed that they fit well into the binding-site, display favourable interactions with the crucial amino acid residues of $E$. coli FabH and suggest good affinity for the enzyme. However, the potency of the compound $\mathbf{5 a}$ was mentioned in $E$. coli by reducing the content of fatty acids. This is a serious issue since $E$. coli is known to cause idiopathic epilepsy by its capability of penetrating blood-brain-barrier (BBB). E. coli $\beta$-ketoacylACP synthase (KAS) I which contributes to thiolactomycin resistance in E. coli was inhibited as shown by in silico results. This enzyme is essential for bacterial survival as it is involved in fatty acid biosynthesis. The in vitro results showed that compounds are effectively inhibiting all the essential fatty acids required for bacterial cell wall construction since they can completely inhibit the function of arachidonic acids.

The synthesized compounds can be divided by two rings: ring $A$ and ring $B$, each ring possesses at least either halogen atom or nitro group. Compound $\mathbf{5 a}$ has two chlorine atoms on ring $A$ and one nitro group on ring $B$, having interactions with $A s n^{274}$ and $C y s{ }^{112}$, makes it promising antibacterial drugs as shown by in vitro and in silico studies on E. coli FabH. This is clearly explained by its in vitro antibacterial capacity. Compound $\mathbf{5 b}$ has nitro group on ring $A$, fluorine atom on the ring $B$ and, it showed interaction with $\mathrm{Asn}^{274}$ and Cys ${ }^{112}$. As the compounds $\mathbf{5 a}$ and $\mathbf{5 b}$ showed the interaction with $\mathrm{Cys}{ }^{112}$ and $\mathrm{Asn}^{247}$ which were two amino acids of the said triad, their ability in inhibition could be confirmed by the fatty acid inhibition results. However, all the synthesized compounds have many hydrophobic interactions with the mentioned protein. Hydrophobic interactions 


\section{Ligand RMSF}

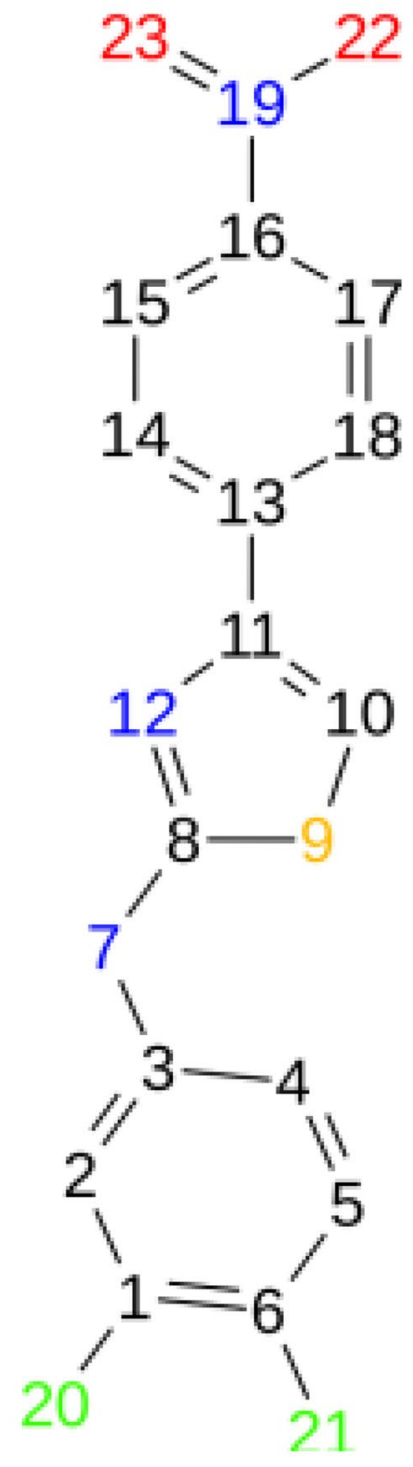

Fig. 17 Ligand RMSF make a large contribution to the stability of the protein structure. Having hydrophobic interactions can alter the protein stability as well as activity. In general, all the synthesized compounds have minimal activity on the rest of tested microorganisms.

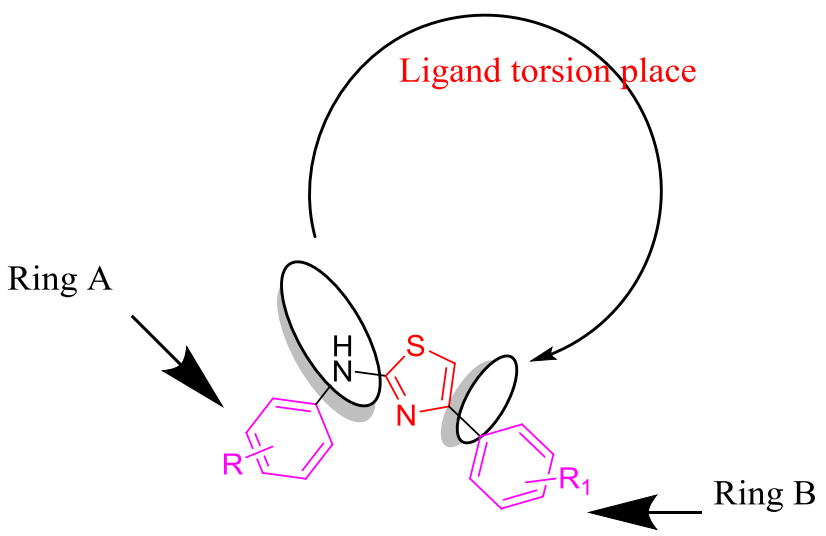

\section{Conclusions}

New aminothiazole derivatives were well designed synthesized and screened for their antibacterial activities. Their structure was assigned by analytical and spectroscopic techniques such as NMR, FT-IR and LCMS. The structure of the compound $\mathbf{5 d}$ was supported by single crystal XRD results. The ten novel synthesized thiazole derivatives showed promising potency against the tested bacterial microorganisms. The compounds (5a, 5b $, 5 \mathbf{c}, \mathbf{5} \mathbf{d}, \mathbf{5 e}$ and 5i) were potent against E. coli (MTCC 443), while compounds $(\mathbf{5 a}, \mathbf{5 e}, \mathbf{5} \mathbf{f}$ and $\mathbf{5 i})$ showed promising potency against $C$. violaceum MCC 2216. Compounds 5a, 5e, $\mathbf{5 g}$ and $\mathbf{5 h}$ showed potent activity against $E$. faecalis MTCC 2729. The potency of the mentioned compounds against $E$. coli (MTCC 443) was confirmed by in silico studies against E. coli FabH (PDB ID-5BNR). However none of tested compounds were potent enough to inhibit the growth of $S$. Aureus (MCC 2043). Among all tested compounds, the compound $\mathbf{5} \mathbf{a}$ was the most potent one against all tested strains with MIC of $5.33 \mu \mathrm{M}$ which was comparable with

Fig. 18 The ligand fluctuations

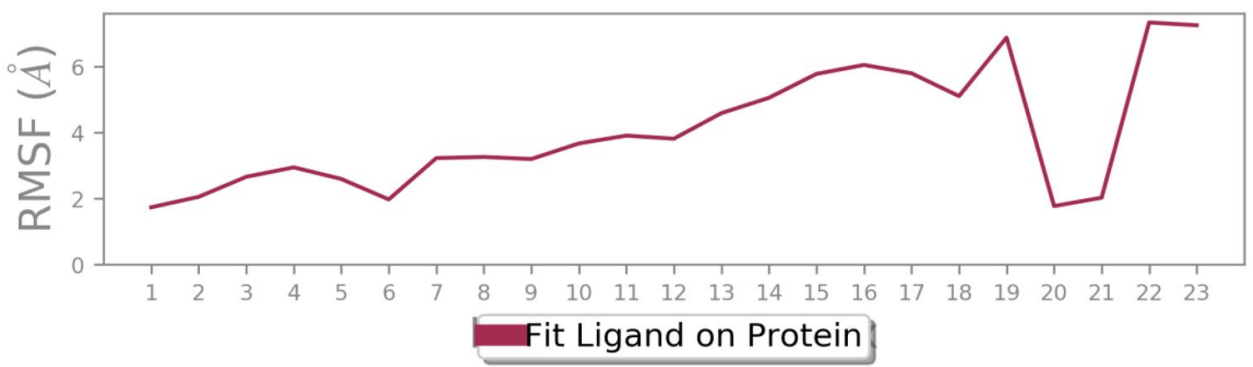

SN Applied Sciences 
Fig. 19 Protein-ligand contacts
Protein-Ligand Contacts

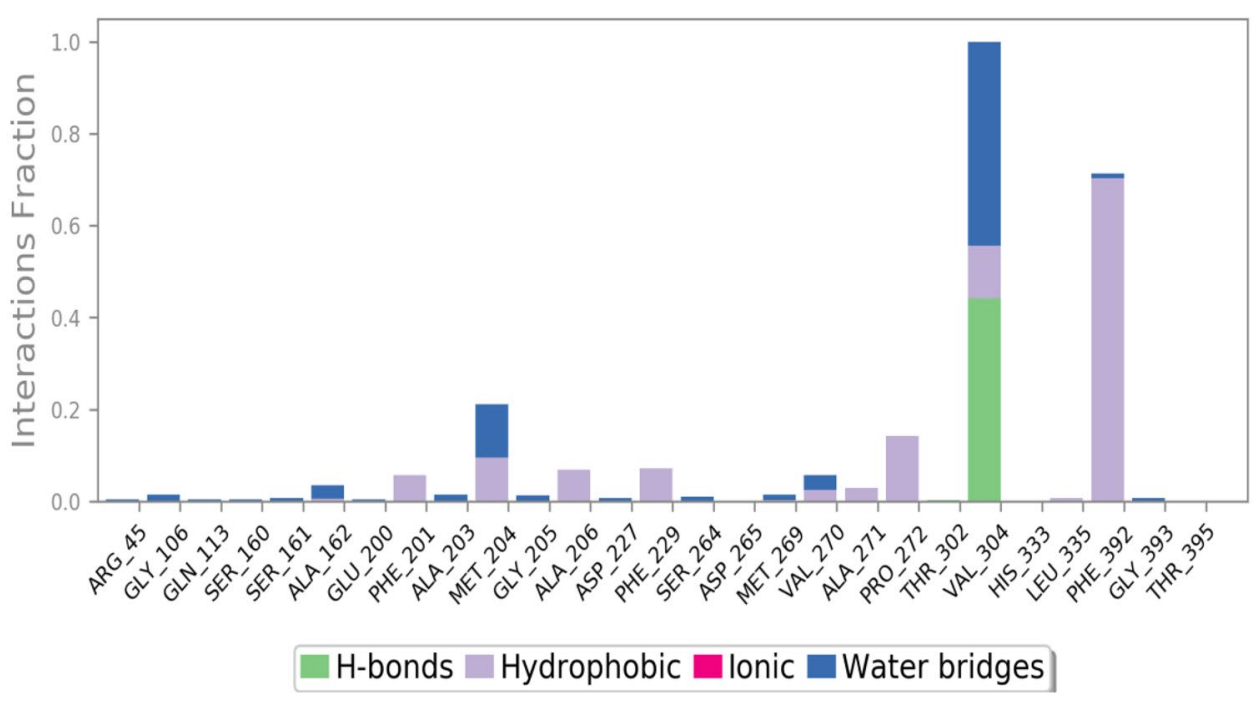

Protein-Ligand Contacts (cont.)

Fig. 20 Protein-ligand contacts (cont.) standard streptomycin. Molecular docking results of the title compounds showed many interactions of them with the E. coli $\beta$-ketoacyl-ACP synthase (KAS) I which contributes to thiolactomycin resistance in $E$. coli. This enzyme is essential for bacterial survival as it is involved in fatty acid biosynthesis. The in vitro fatty acids inhibition results showed that compounds are effectively inhibiting all the essential fatty acids required for bacterial cell wall construction since they can completely inhibit the function of arachidonic acids. It is well understood that $E$. coli even penetrates blood-brain barrier [27], hence its capacity of generating idiopathic epilepsy [28]. In silico results complemented in vitro study results. All the tested compounds were found to possess minimum toxicity towards human blood cells. Molecular dynamic simulations done for the compound $\mathbf{5 a}$ emphasized the affinity as well as the stability of the ligand with the protein during contact.

\section{Experimental sections}

All required reagents were used as received from suppliers without further purification. The melting point was measured in open capillary tube and correction is not applied. The IR-spectrum was recorded on Shimadzu
FT-IR Prestige-21 spectrophotometer in ATR mode and is expressed in $\mathrm{cm}^{-1}$. The mass spectrum was obtained using Shimadzu LC MS-8030 mass spectrometer operating at $70 \mathrm{eV}$. The ${ }^{1} \mathrm{H}$ NMR and ${ }^{13} \mathrm{C}$ NMR spectra were recorded on a Bruker AVANCE II $400 \mathrm{MHz}$ instrument in $\mathrm{CDCl}_{3} / \mathrm{DMSO}$ $d_{6}$ solvent and TMS as an internal standard. The purity of the compound and completion of the reaction were monitored by TLC using Merck silica gel $60 \mathrm{~F}_{256}$ coated Aluminum with petroleum ether: ethyl acetate (8:2) as mobile phase. Elemental analysis was carried out.

\subsection{General procedure for the synthesis of title compounds $5 a-j$}

Equimolar amounts of substituted phenylthioureas 2 $(0.01 \mathrm{M})$ and 4-substituted phenacylbromides $4(0.01 \mathrm{M})$ in $30 \mathrm{~mL}$ ethanol was heated under reflux for $24 \mathrm{~h}$. The TLC (ethyl acetate/petroleum ether, 8:2) was used to confirm the completion of the reaction. After cooling, separated solid was filtered, dried and recrystallized from ethanol to yield compounds $\mathbf{5} \mathbf{a}-\mathbf{j}$. The spectral data confirming the identity of the synthesized compounds are given below. 
Fig. 21 The Figure 21 clearly showed that the contact is maintained and is showed by a darker shade of orange colour. From the figure above, we can detect more than 6 specific contacts which are $\mathrm{Phe}^{392}$ $\mathrm{Val}^{304}, \mathrm{Met}^{204}, \mathrm{Phe}^{201}, \mathrm{Ala}^{162}$ and Gly ${ }^{106}$

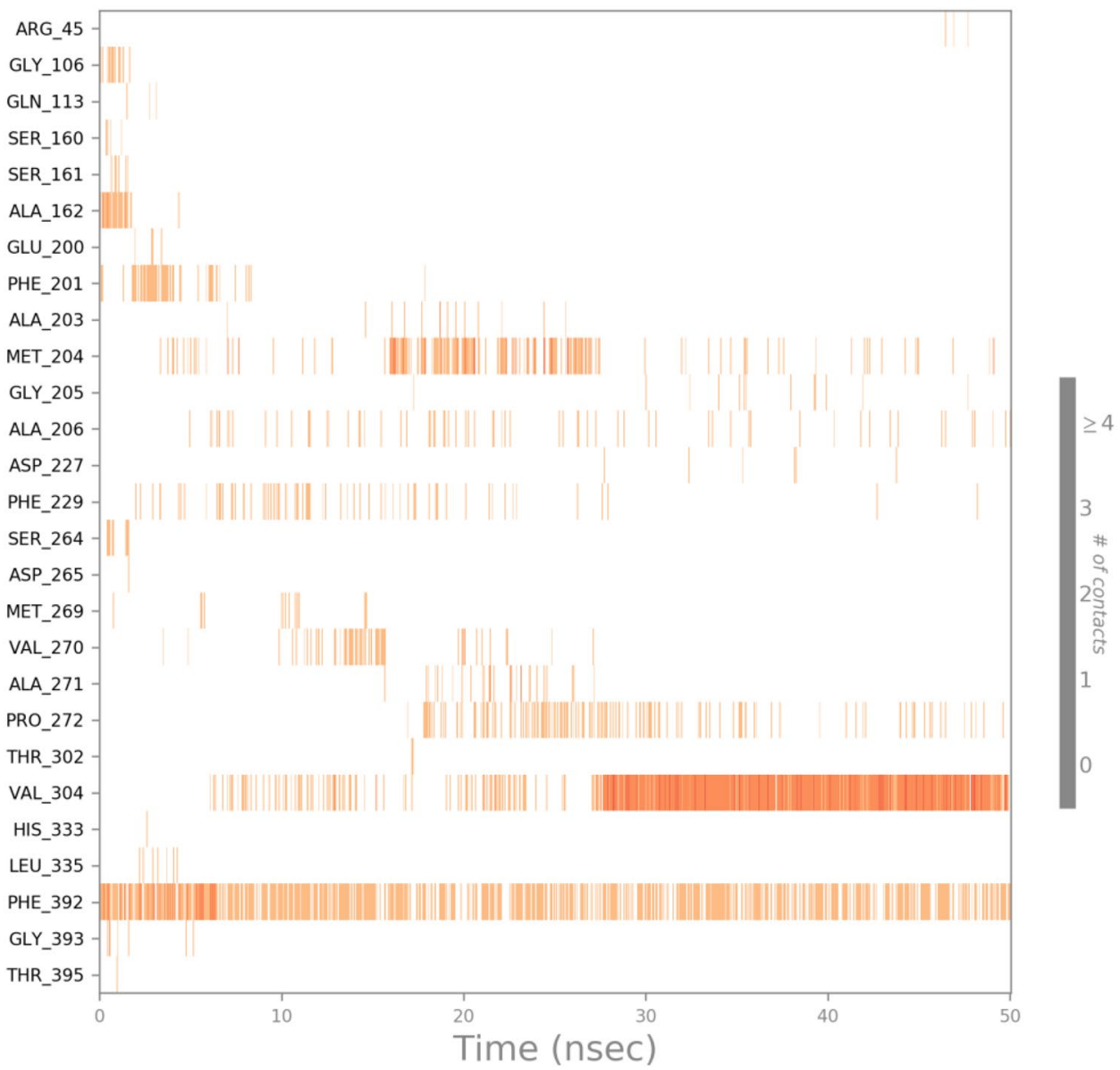

\subsubsection{N-(3,4-Dichlorophenyl)-4-(4-nitrophenyl) thiazol-2-amine (5a)}

Orange solid, MP: $180-182{ }^{\circ} \mathrm{C}$; Yield: $65 \%$. IR $\left(\mathrm{KBr}, \mathrm{vcm}^{-1}\right)$ : 3126 (NH stretch), 3047 (C-H stretch), 1616 (C=C), 1552 (N-O asym stretch), $1494(\mathrm{C}=\mathrm{N}), 1319(\mathrm{~N}-\mathrm{O}$ sym. stretch), $725(\mathrm{C}-\mathrm{Cl}) .{ }^{1} \mathrm{HNMR}\left(400 \mathrm{MHz}, \mathrm{DMSO}-d_{6}\right): \delta(\mathrm{ppm}) 7.62-7.65$ (d, $J=8 \mathrm{~Hz}$, ortho protons of 4- $\mathrm{NO}_{2}$ phenyl); 8.24-8.26(d, $J=8 \mathrm{~Hz}$, meta protons of 4- $\mathrm{NO}_{2}$-phenyl), 8.11-8.13 (d, $J=8 \mathrm{~Hz}$, ortho proton of 3,4-dichlorophenyl), 8.17 (s, ortho proton of 3,4-dichlorophenyl ring), 7.47 (s, thiazole proton), and the exocyclic $\mathrm{NH}$ proton appeared at $\delta$ (ppm) 10.58 as a singlet. ${ }^{13} \mathrm{CNMR}\left(100 \mathrm{MHz}, \mathrm{DMSO}-d_{6}, \delta\right.$ ppm):162.7, 148.1, 146.2, 140.6, 131.3, 130.2, 126.2, 123.7, 122.6, 118.0, 116.7 and 107.8). Elemental analysis: Anal. Calcd.C, 49.20; H, 2.48; N, 11.47. Found: C, 49.25; H, 2.46; N, 11.48; LCMS: (m/z): $\mathrm{C}_{15} \mathrm{H}_{8} \mathrm{~N}_{3} \mathrm{Cl}_{2} \mathrm{O}_{2} \mathrm{~S}: 366.00(\mathrm{M}+\mathrm{H})^{+}, 368.00$ $(\mathrm{M}+\mathrm{H}+2)^{+}, 370.00(\mathrm{M}+\mathrm{H}+4)^{+}$.

\subsubsection{4-(4-Fluorophenyl)- $\mathrm{N}$-(4-nitrophenyl) thiazol-2-amine} (5b)

Orange solid, MP: $180-182{ }^{\circ} \mathrm{C}$; Yield: $65 \%$. IR $\left(\mathrm{KBr}, \mathrm{vcm}^{-1}\right)$ : 3130 (NH stretch), 3045 (C-H stretch), 1094(C=N), 1616
$(\mathrm{C}=\mathrm{C}), 1554$ (N-O asym stretch), 1319 (N-O sym stretch), $1056(\mathrm{C}-\mathrm{F}) .{ }^{1} \mathrm{H}-\mathrm{NMR}\left(400 \mathrm{MHz}, \mathrm{DMSO}-d_{6}\right): \delta$ (ppm) 7.12-7.14 [2H, d, $(J=8 \mathrm{~Hz})$, ortho protons of 4-nitrophenyl]; 8.17-8.19 [(2H, d $(J=8 \mathrm{~Hz})$ meta protons of 4-nitrophenyl]; 7.90-7.93 [2H, dd $(J=12 \mathrm{~Hz}, J=4 \mathrm{~Hz}$ ) (HF ortho) meta protons 4-fluorophenyl], 7.93-7.95 [2H, dd [J=8 Hz, $J=4 \mathrm{~Hz}$ ) (HF meta) 4-fluorophenyl ring], and the exocyclic $\mathrm{NH}$ proton appeared at $\delta$ (ppm) 10.94 as a singlet. ${ }^{13} \mathrm{CNMR}$ (100 MHz, DMSO- $d_{6}, \delta$ ppm): 161.8, 151.4, 149.7, 146.9, 140.3, 127.7, 125.6, 116.1, 115.4 and 114.1. Elemental analysis: Calcd.C, 57.14; H, 3.20; N, 13.33. Found: $C, 57.15 ; \mathrm{H}$, 3.19; $\mathrm{N}, 13.34$.). LCMS: (m/z): $\mathrm{C}_{15} \mathrm{H}_{10} \mathrm{~N}_{3} \mathrm{FO}_{2} \mathrm{~S}: 356.05(\mathrm{M}+\mathrm{H})^{+}$.

\subsubsection{4-(4-Chlorophenyl)- $N$-(3,4-dichlorophenyl) thiazol-2-amine $(5 \mathrm{c})$}

Lemon yellow solid, MP: $118-120^{\circ} \mathrm{C}$; Yield: $65 \%$. IR ( $\mathrm{KBr}$, $\left.\mathrm{vcm}^{-1}\right): 3178$ (NH stretch), $3039(\mathrm{C}-\mathrm{H}$ stretch), $1632(\mathrm{C}=\mathrm{N})$, $725(\mathrm{C}-\mathrm{Cl}) .{ }^{1} \mathrm{H}-\mathrm{NMR}\left(400 \mathrm{MHz}, \mathrm{DMSO}-d_{6}\right): \delta$ (ppm) 7.26 (thiazole), $7.88-7.90(\mathrm{~d}, 2 \mathrm{H}, J=8 \mathrm{~Hz}$, ortho protons of -4-chlorophenyl ring); $7.43-7.40(\mathrm{~d}, 2 \mathrm{H}, J=12 \mathrm{~Hz}$, metaprotons of 4-chlorophenyl ring), $8.09-8.10(\mathrm{~d}, 1 \mathrm{H}, J=4 \mathrm{~Hz}$, ortho proton of 3,4-dichlorophenyl ring), 7.45 (s, ortho proton of 


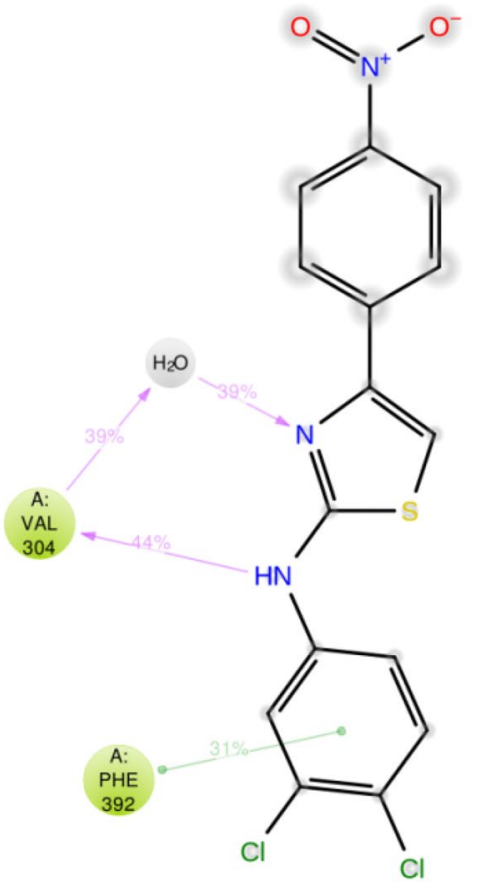

Hydrophobic
Water

\section{Ligand Torsion Profile}<smiles>CN(C(=O)O)c1ccc(-c2ccc(C(=O)O)cc2)cc1</smiles>
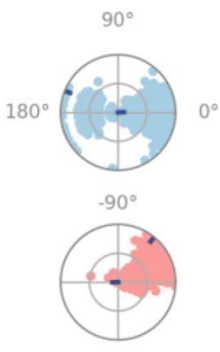
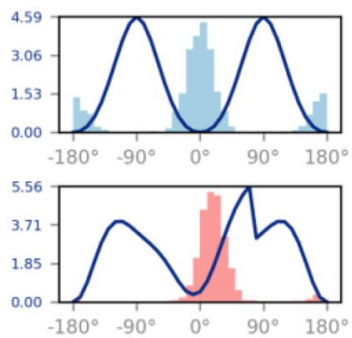
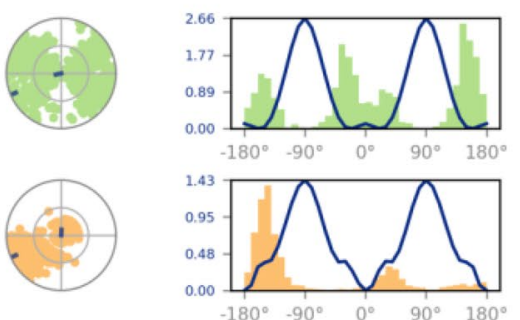

Fig. 23 The figure 23 shows the rotatable bond in the ligand, on left Y-axis is the potential expressed in Kcal/mol and the torsion potential relationship gives awareness into the conformational strain the ligand is undergoing to keep a protein- bond conformation

3,4-dichlorophenyl ring), 7.60-7.63 [dd, $(J=12 \mathrm{~Hz}, J=4 \mathrm{~Hz}$, (meta proton of 3,4-dichlorophenyl ring)], and the exocyclic NH proton appeared at $\delta(\mathrm{ppm}) 10.45$ as a singlet. ${ }^{13} \mathrm{CNMR}\left(100 \mathrm{MHz}\right.$, DMSO- $\left.d_{6}, \delta \mathrm{ppm}\right): 162.4,148.9,140.8$, 133.0, 132.2, 131.3, 130.2, 128.4, 127.0, 122.3, 117.9, 116.6 and 103.9. Elemental analysis: Calcd: Anal. Calcd.C, 49.20; $\mathrm{H}, 2.48 ; \mathrm{N}, 11.47$. Found: $\mathrm{C}, 49.21 ; \mathrm{H}, 2.47 ; \mathrm{N}, 11.48$. LCMS: $(\mathrm{m} / \mathrm{z}): \mathrm{C}_{15} \mathrm{H}_{9} \mathrm{~N}_{2} \mathrm{Cl}_{3} \mathrm{~S}: 355.85(\mathrm{M}+\mathrm{H})^{+}, 357.85(\mathrm{M}+\mathrm{H}+2)^{+}$, $359.85(\mathrm{M}+\mathrm{H}+4)^{+}, 361.85(\mathrm{M}+\mathrm{H}+6)^{+}$.

\subsubsection{N-(2,6-Dimethylphenyl)-4-(4-chlorophenyl) thiazol-2-amine (5d)}

Greyish white solid, MP: $220-222^{\circ} \mathrm{C}$; Yield: $65 \%$. IR (KBr, $\mathrm{vcm}^{-1}$ ): 3143 (NH stretch), 3043 (Ar-H stretch), 2929 (C-H alkyl stretch), $1573(\mathrm{C}=\mathrm{C}), 1184(\mathrm{C}=\mathrm{N}), 729(\mathrm{C}-\mathrm{Cl}) .{ }^{1} \mathrm{HNMR}$ $\left(400 \mathrm{MHz}, \mathrm{DMSO}-d_{6}\right): \delta$ (ppm) 6.63 (Ar-H-thiazole), 7.66-7.68 $(\mathrm{d}, 2 \mathrm{H}, J=8 \mathrm{~Hz}$, ortho protons of 4-chlorophenyl); $7.25-7.28(\mathrm{~d}, 2 \mathrm{H}, J=8.8 \mathrm{~Hz}$, meta protons of 4-chlorophenyl ring), $7.20-7.21(\mathrm{~d}, 2 \mathrm{H}, J=4 \mathrm{~Hz}$, meta proton 
Fig. 24 Ligand properties

Ligand Properties

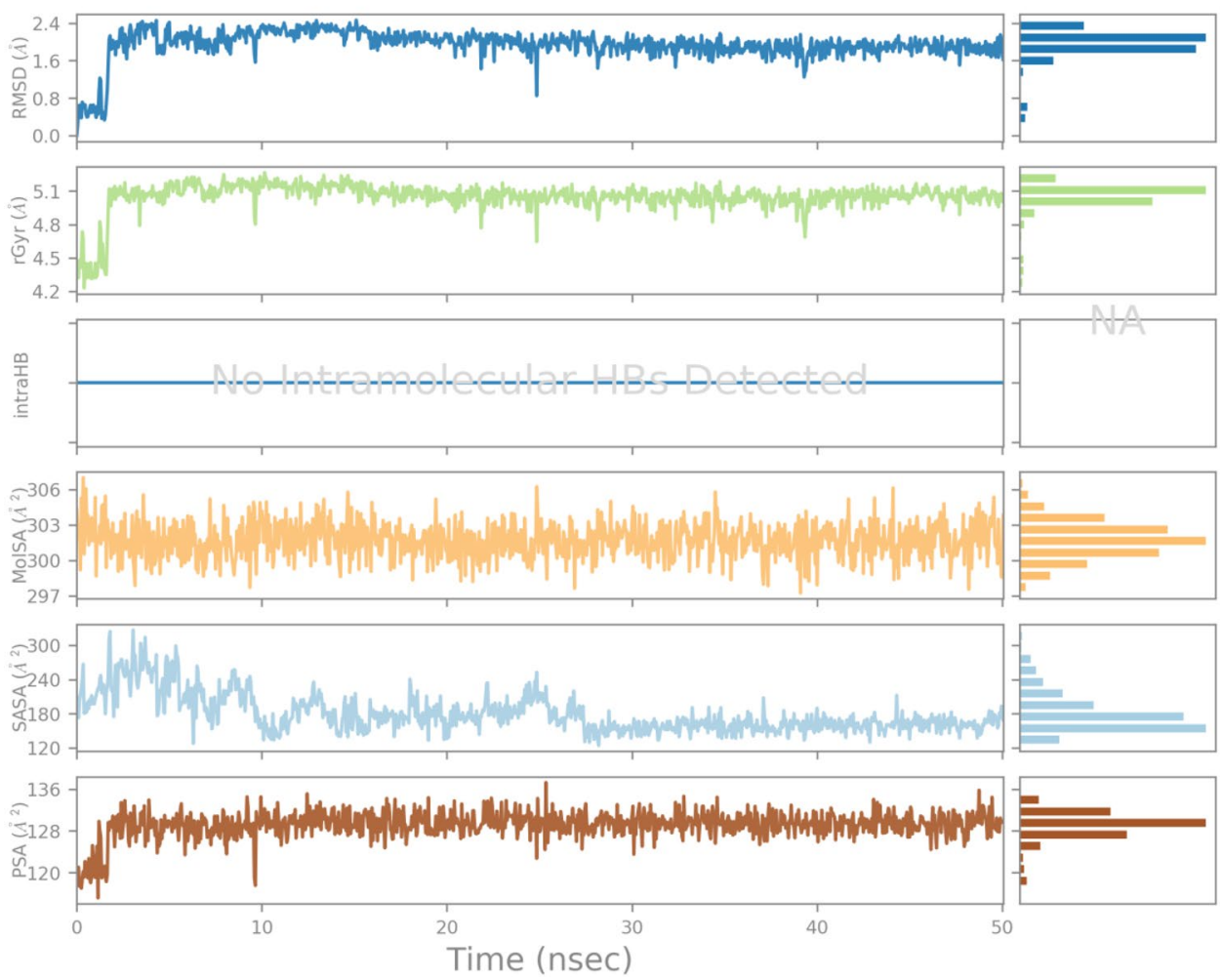

of 2,6-methylphenyl ring), 7.19-7.20 (d, $1 \mathrm{H}, J=4 \mathrm{~Hz}, 1 \mathrm{H}$, meta proton of 2,6-dimethylphenyl ring), 7.17-7.16 (d, $\mathrm{Ar}-\mathrm{H}, J=4 \mathrm{~Hz}$; para proton of 2,6-dimethylphenyl ring), $2.32\left(\mathrm{~s}, 6 \mathrm{H}\right.$, alkyl. ${ }^{13} \mathrm{CNMR}\left(100 \mathrm{MHz}, \mathrm{DMSO}-d_{6}, \delta \mathrm{ppm}\right)$ : 168.4, 149.1, 137.7, 135.9, 133.4, 131.8, 128.2, 127.0, 126.7, 101.8 and 17.9. Elemental analysis: Anal. Calcd.C, 64.86; $H, 4.80 ; N, 8.90$. Found: $C, 64.85 ; H, 4.81 ; N, 8.89$. LCMC: $(\mathrm{m} / \mathrm{z}): \mathrm{C}_{17} \mathrm{H}_{15} \mathrm{~N}_{2} \mathrm{ClS}: 315.00(\mathrm{M}+\mathrm{H})^{+}, 317.00(\mathrm{M}+\mathrm{H}+2)^{+}$.

\subsubsection{N-(3-Chloro-2-methylphenyl)-4-(4-nitrophenyl) thiazol-2-amine (5e)}

Yellow solid, MP: $180-182{ }^{\circ} \mathrm{C}$; Yield: $65 \%$. IR $\left(\mathrm{KBr}, \mathrm{vcm}^{-1}\right)$ : 3130 (NH stretch), 3039 (Ar-H stretch), 2860 (C-H alkyl stretch), $1618(\mathrm{C}=\mathrm{C}), 1554(\mathrm{~N}-\mathrm{O}$ asym stretch), $1494(\mathrm{C}=\mathrm{N})$, 1319 (N-O sym stretch),725 (C-Cl). ${ }^{1} \mathrm{H}-\mathrm{NMR}(400 \mathrm{MHz}$, DMSO- $\left.d_{6}\right): \delta$ (ppm) $9.61(\mathrm{~s}, \mathrm{~N}-\mathrm{H}), 7.59$ (s, 1H thiazole), $8.08-8.10[\mathrm{~d},(J=8 \mathrm{~Hz}$, ortho protons of 4-nitrophenyl ring $)$; $8.21-8.23[(\mathrm{~d},(\mathrm{~J}=8 \mathrm{~Hz})$ meta protons of 4-nitrophenyl ring]; 8.25 [s, para proton of 2-methyl-3-chlorophenyl ring), $7.94-7.96(d, J=8 \mathrm{~Hz}$, ortho proton of 2-methyl-3-chlorophenylring), 7.17-7.23 (dd, $J=24 \mathrm{~Hz}$, $\mathrm{J}=8 \mathrm{~Hz}$, meta proton of 2-methyl-3-chlorophenyl ring). ${ }^{13} \mathrm{CNMR}\left(100 \mathrm{MHz}\right.$, DMSO- $d_{6}, \delta$ ppm): 165.5, 147.8, 146.1, $140.5,134.1,127.2,126.8,124.1,123.7,120.0,107.6$ and 14.8. Elemental analysis: Anal. Calcd. C, 55.57; H, 3.50;
$\mathrm{N}, 12.15$. Found: $\mathrm{C}, 55.58 ; \mathrm{H}, 3.48 ; \mathrm{N}, 12.14$. LCMS: (m/z): $\mathrm{C}_{16} \mathrm{H}_{12} \mathrm{~N}_{3} \mathrm{ClO}_{2} \mathrm{~S}: 346.00(\mathrm{M}+\mathrm{H})^{+}, 348.00(\mathrm{M}+\mathrm{H}+2)^{+}$.

\subsubsection{N-(3-Chloro-2-methylphenyl)-4-(4-chlorophenyl) thiazol-2-amine (5f)}

White solid, MP: $200-202{ }^{\circ} \mathrm{C}$; Yield: $65 \%$. IR $\left(\mathrm{KBr}_{\mathrm{vcm}}{ }^{-1}\right)$ : 3130 (NH stretch), 3039 (Ar-H stretch), 2926(C-H alkyl stretch), $1494(\mathrm{C}=\mathrm{N}), 1618(\mathrm{C}=\mathrm{C}), 1056(\mathrm{C}-\mathrm{F}) .{ }^{1} \mathrm{H}-\mathrm{NMR}$ $\left(400 \mathrm{MHz}, \mathrm{DMSO}-d_{6}\right): \delta$ (ppm), 7.93-7.95 [dd, $(J=16 \mathrm{~Hz}$, $J=8 \mathrm{~Hz}, \mathrm{H}-\mathrm{Cl}$ ortho) meta protons of 4-chlorophenyl ring $)$; 7.84-7.85 [(d, $(J=4 \mathrm{~Hz}, \mathrm{H}-\mathrm{Cl}$ meta) ortho protons of 4-chlorophenyl ring]; 7.82-7.83 (d, $(J=4 \mathrm{~Hz}$, ortho proton), 7.13 (s, thiazol proton. $7.43-7.45$ (d, $J=8 \mathrm{~Hz}$, meta proton of 2-methyl-3-chlorophenyl ring), 7.34-7.36 (d, $J=8 \mathrm{~Hz}$, ortho proton of 2-methyl-3-chlorophenyl ring), $2.35(\mathrm{~s}, 3 \mathrm{H}, 4$-chlorophenyl ring) and the exocyclic $\mathrm{NH}$ proton appeared at $\delta$ (ppm) 9.45 as a singlet. ${ }^{13} \mathrm{CNMR}$ (100 MHz, DMSO- $d_{6}, \delta$ ppm): 166.1, 164.0, 146.1, 140.3, 134.4, 130.0, 129.9, 127.7, 126.9, 124.8, 120.7, 115.3, 114.8, 102.7 and 14.9. Elemental analysis:Anal. Calcd.C, 60.28; $\mathrm{H}, 3.79 ; \mathrm{N}, 8.79$. Found: $\mathrm{C}, 60.26 ; \mathrm{H}, 3.80 ; \mathrm{N}, 8.78$. LCMS: $(\mathrm{m} / \mathrm{z}): \mathrm{C}_{16} \mathrm{H}_{12} \mathrm{~N}_{2} \mathrm{ClFS}: 319.00(\mathrm{M}+\mathrm{H})^{+}, 321.00(\mathrm{M}+\mathrm{H}+2)^{+}$. 


\subsubsection{N-(3-Chloro-2-methylphenyl)-4-(4-methoxyphenyl) thiazol-2-amine $(5 \mathrm{~g})$}

Off white solid, MP: $208-210^{\circ} \mathrm{C}$; Yield: $65 \%$. IR $\left(\mathrm{KBr}, \mathrm{vcm}{ }^{-1}\right)$ : 3053(NH stretch), 3053 (Ar-H), 2966 (C-H-alkyl), 1562 $(\mathrm{C}=\mathrm{C}), 1506(\mathrm{C}=\mathrm{N}), 1055$ (C-O stretch), $732(\mathrm{C}-\mathrm{Cl}) .{ }^{1} \mathrm{H}-\mathrm{NMR}$ $\left(400 \mathrm{MHz}, \mathrm{DMSO}-d_{6}\right): \delta(\mathrm{ppm}) 11.32(\mathrm{~s}, \mathrm{~N}-\mathrm{H}), 7.42-7.44(\mathrm{Ar}-\mathrm{H}$, $\mathrm{d}, J=8 \mathrm{~Hz}$, protons of 2-methyl3-chlorophenyl)]; 7.33-7.35 (d, $J=8 \mathrm{~Hz}$ ) protons of 2-methyl-3-chlorophenyl ring]; 7.23-7.25 $[\mathrm{d},(\mathrm{J}=8 \mathrm{~Hz})$ protons of 4-methoxyphenyl ring], 7.00-7.02 [d, $J=8 \mathrm{~Hz}$, 4-meta protons of methoxyphenyl ring, 7.74-7.72 ( $2 \mathrm{H}, \mathrm{d}$, ortho 4-methoxyphenyl ring), 3.8 (s, 3H of alkyl methoxy), 2.5 (3H, s, alkyl). ${ }^{13} \mathrm{CNMR}\left(100 \mathrm{MHz}\right.$, DMSO- $\left.d_{6}, \delta \mathrm{ppm}\right)$ : $159.2,140.1,139.7,134.4,129.1,127.2,113.7,100.9$ and 14.8 . Elemental analysis: Anal. Calcd. C, 61.72; H, 4.57; N, 8.47. Found: $\mathrm{C}, 61.74 ; \mathrm{H}, 4.55 ; \mathrm{N}$, 8.46. LCMS: (m/z): $\mathrm{C}_{17} \mathrm{H}_{15} \mathrm{~N}_{2} \mathrm{ClOS}$ : $331.05\left(\mathrm{M}+\mathrm{H}^{+}\right), 333.05(\mathrm{M}+\mathrm{H}+2)^{+}$.

\subsubsection{4-(4-Chlorophenyl)-N-(4-fluoro-2-methylphenyl) thiazol-2-amine (5h)}

Pale violet solid, MP: $135-137^{\circ} \mathrm{C}$; Yield: $65 \%$; IR $\left(\mathrm{KBr}, \mathrm{vcm}^{-1}\right)$ : $3126(\mathrm{NH}), 3049(\mathrm{Ar}-\mathrm{H}), 2856(\mathrm{C}-\mathrm{H}$-alkyl), $1616(\mathrm{C}=\mathrm{C}), 1496$ $(\mathrm{C}=\mathrm{N}), 1056(\mathrm{C}-\mathrm{F}), 725(\mathrm{C}-\mathrm{Cl}),{ }^{1} \mathrm{H}$ NMR $\left(\mathrm{CDCl}_{3}, 400 \mathrm{MHz}\right)$ $\delta$ ppm: $2.26(\mathrm{~s}, 3 \mathrm{H}$ alkyl). 7.64-7.65 (d, 2H, ortho protons of 4-chlorophenylring),6.94-6.96 (d, $2 \mathrm{H}$, meta protonsof 4-chlorophenyl ring), 7.66-7.67 (d, $1 \mathrm{H}, J=4 \mathrm{~Hz}$, proton of 2-methyl-4-fluorophenyl ring), 7.49-7.52 (dd, $2 \mathrm{H}, J=12 \mathrm{~Hz}$, $J=4 \mathrm{~Hz}$, meta protons of 2-methyl-4-fluorophenyl ring). ${ }^{13} \mathrm{C}-\mathrm{NMR}$ (DMSO- $\left.d_{6}, 100 \mathrm{MHz}\right) \delta$ ppm: $166.2,159.7,157.3$, $148.8,135.5,133.3,132.5,128.3,127.1,123.6,116.9,112.8$, 102.8 and 18.1). Elemental analysis: Anal. Calcd. C, 60.28; $\mathrm{H}$, 3.79; N, 8.79. Found: $C, 60.29 ; \mathrm{H}, 3.78 ; \mathrm{N}, 8.80$. LCMS: (m/z): $\mathrm{C}_{16} \mathrm{H}_{12} \mathrm{~N}_{2} \mathrm{CIFS}: 318.95\left(\mathrm{M}+\mathrm{H}^{+}\right), 320.95(\mathrm{M}+\mathrm{H}+2)^{+}$.

\subsubsection{N-(2,6-Dimethylphenyl)-4-(4-fluorophenyl) thiazol-2-amine (5i)}

Peach solid, MP: $150-152{ }^{\circ} \mathrm{C}$; Yield: $69.29 \%$; IR $\left(\mathrm{KBr}, \mathrm{vcm}^{-1}\right)$ : $3126(\mathrm{NH}), 3047$ (Ar-H), 2856 (CH alkyl), $1616(\mathrm{C}=\mathrm{C}), 1496$ $(\mathrm{C}=\mathrm{N}), 1056(\mathrm{C}-\mathrm{F}), 725(\mathrm{C}-\mathrm{Cl}) .{ }^{1} \mathrm{H}$ NMR $\left(\mathrm{CDCl}_{3}, 400 \mathrm{MHz}\right)$ $\delta$ ppm: 2.32 (s, 6H, alkyl), 6.57 (s, thiazole), 7.21-7.13 (m, $3 \mathrm{H}, 2,6$-dimethylphenyl ring),7.73-6.99 (dd, $J=16 \mathrm{~Hz}$, $J=4 \mathrm{~Hz}, 2 \mathrm{H}$ of meta 4-fluorophenyl ring), 7.01-6.97 (dd, $J=16 \mathrm{~Hz}, J=4 \mathrm{~Hz}, 2 \mathrm{H}$ of ortho 4 -fluorophenyl ring). ${ }^{13} \mathrm{C}-$ NMR (DMSO- $d_{6}, 100 \mathrm{MHz}$ ) $\delta$ ppm: 168.6, 162.7, 160.3, 149.4, 137.9, 136.0, 131.2, 128.3, 127.4, 126.8, 115.1, 114.9, 100.8 and 18.0. Elemental analysis: Anal. Calcd. C, 53.11; H, 2.67; $\mathrm{N}, 8.26$. Found: $\mathrm{C}, 53.13 ; \mathrm{H}, 2.66 ; \mathrm{N}, 8.24$. LCMS: (m/z): $\mathrm{C}_{15} \mathrm{H}_{9} \mathrm{~N}_{2} \mathrm{Cl}_{2} \mathrm{FS}: 295.05(\mathrm{M}+\mathrm{H})^{+}$.

\subsubsection{N-(2,6-Dimethylphenyl)-4-(4-nitrophenyl) thiazol-2-amine (5j)}

Yellow solid, MP: $158-160^{\circ} \mathrm{C}$; Yield: $50.13 \%$; IR $\left(\mathrm{KBr}, \mathrm{vcm}^{-1}\right)$ : $3169(\mathrm{NH}), 3051(\mathrm{Ar}-\mathrm{H}), 2846(\mathrm{C}-\mathrm{H}$ alkyl), $1595(\mathrm{C}=\mathrm{C}), 1504$ ( $\mathrm{N}-\mathrm{O}$ asym stretch), $1504(\mathrm{C}=\mathrm{N}), 1321$ ( $\mathrm{N}-\mathrm{O}$ symstretch), $1056(\mathrm{C}-\mathrm{F}) .{ }^{1} \mathrm{H}$ NMR $\left(\mathrm{CDCl}_{3}, 400 \mathrm{MHz}\right) \delta \mathrm{ppm}: 2.32(\mathrm{~s}$, $6 \mathrm{H}$, alkyl); $7.86(\mathrm{~s}, \mathrm{Ar}-\mathrm{H}$, thiazole ring); $7.21-7.15(\mathrm{~m}, 3 \mathrm{H}$, 2,6-dimethylphenyl ring); $8.14-8.12(\mathrm{~d}, J=8 \mathrm{~Hz}, 2 \mathrm{H}$ of ortho 4-nitrophenyl ring), $7.87-7.85(\mathrm{~d}, J=8 \mathrm{~Hz}, 2 \mathrm{H}$ of meta of 4-nitrophenyl ring). ${ }^{13} \mathrm{C}-\mathrm{NMR}$ (DMSO- $\left.d_{6}, 100 \mathrm{MHz}\right) \delta \mathrm{ppm}$ : $168.7,148.3,145.9,140.7,137.5,135.9,128.2,126.9,123.5$, 105.8 and 17.9. Elemental analysis: Anal. Calcd. C, 62.75; $\mathrm{H}, 4.65 ; \mathrm{N}, 12.91$. Found: $\mathrm{C}, 62.76 ; \mathrm{H}, 4.64 ; \mathrm{N}, 12.92$. LCMS: $(\mathrm{m} / \mathrm{z}): \mathrm{C}_{17} \mathrm{H}_{15} \mathrm{~N}_{3} \mathrm{O}_{2} \mathrm{~S}: 326.00(\mathrm{M}+\mathrm{H})^{+}$.

\subsection{Antibacterial evaluation}

The resistance of biological infections on available drugs has been reported wide worldly; therefore researchers have to focus toward the new antimicrobial drugs with new target [29]. The synthesized compounds were screened in vitro for their antibacterial activity against four referential strains namely, E. coli MTCC 443 and C. violaceum MCC 2216 (Gram-negative), S. aureus MCC 2043 and E. faecalis MTCC 2729 (Gram positive), using the disc diffusion method [30]. Thus, disinfected plates were filled with $20 \mathrm{~mL}$ of sterilized Muller Hinton agar medium. Afterwards, $100 \mathrm{~mL}$ of particular bacterium which contained of 0.5-106 CFU mL (tantamount to 0.5 McFarland standards) was dispersed on the plates surfaces using a sterile swab. The discs which had been impregnated with $(15 \mu \mathrm{L})$ the each compound with ( $25 \mathrm{mg} \mathrm{mL}^{-1}$ in DMSO) and were placed on the agar surface. The disc soaked in the DMSO was used as negative control. The plates were incubated at $37^{\circ} \mathrm{C}$ for $24 \mathrm{~h}$, and the diameter of the zones of inhibition was measured in millimetres $(\mathrm{mm})$. The sample test was performed in three replicates. Compounds showing significant zone of inhibition were subjected to minimum inhibitory concentration (MIC). MICs were performed in MH Broth in 96-well microplates by a dilution method. Tantamount to $0.5 \mathrm{McF}$ arland standards, exponential bacterial cultures $\left(1.5 \times 10^{8}\right.$ c.f.u) were obtained, added to wells containing decreasing concentrations of the compounds. The 96-well microplates were incubated at $37^{\circ} \mathrm{C}$ overnight and the MIC was determined as the lowest concentration that inhibits the visible growth of the microorganism. The stock solution of the test compound was made with $1 \mathrm{mg} \mathrm{mL}^{-1}$ along with the standard drug streptomycin. 


\subsection{Fatty acid inhibition study}

Fatty acid methyl esters were prepared using Metcalfe method in duplicate from bacterial isolates $(100 \mu \mathrm{L})$ in the presence of Triheptadecanoin (internal standard); NuChek prep, Elysian, MN, USA). Using gas chromatography with flame ionization detection, four fatty acids were accounted. Individual fatty acids are expressed as percent of total acids in a sample. For all samples, data peaks on chromatograms were examined to ensure peak quality and consistency of retention times. Based on retention time of methyl ester derivatives, fatty acids in sample were recognized.

\subsection{Hemolysis assay}

Sashidhara et al. [31] suggested the procedure regarding this assay: The human blood was collected in a container of EDTA ( $2 \mathrm{mg} \mathrm{mL}^{-1}$ ). The resulting suspension was centrifuged at $800 \times g$ for 10 min to separate buffy coat and plasma. Successively, the erythrocytes settled were washed thrice with normal saline $(0.9 \%)$ and then suspended in saline to obtain $5 \%$ erythrocytes suspension. Incubation of the cells was done in $1 \mathrm{~h}$ at $37^{\circ} \mathrm{C}$ in the presence of test compounds $\left(100 \mu \mathrm{g} \mathrm{mL}^{-1}\right)$. Once incubation done, the solutions were centrifuged at $800 \times g$ for $10 \mathrm{~min}$ and then absorbance of the supernatant was measured using UV spectrophotometer at $540 \mathrm{~nm}$. The $2 \%$ Triton X-100 (Sigma-Aldrich, St. Louis, USA) were used as positive control. The absorbance recorded for the released haemoglobin was expressed as \% of Triton X-100 induced hemolysis. The result was calculated by using the formula below:

$\%$ Hemolysis

$$
=\frac{(\text { Absorbance of the sample })-(\text { Absorbance of blank })}{\text { Highest absorbance of positive control }} \times 100
$$

\subsection{Single crystal X-ray diffraction}

The X-ray intensity data for compound $\mathbf{5} \mathbf{d}$ is collected at a temperature of 296 K on a Rigaku Saturn724 diffractometer using graphite monochromated Mo-Ka radiation. A complete data set was processed using Crystal Clear [32]. The structure was solved by direct methods and refined by full-matrix least squares method on F2 using SHELXS and SHELXL programs [33, 34]. All the non-hydrogen atoms were revealed in the first difference Fourier map itself. All the hydrogen atoms were positioned geometrically $(\mathrm{C}-\mathrm{H}$ $=0.93$ (aromatic) $/ 0.96$ (methyl) $\AA, \mathrm{N}-\mathrm{H}=0.86 \AA$ ) and refined using a riding model with Uiso $(\mathrm{H})=1.2 \mathrm{Ueq}(\mathrm{C}$ or $\mathrm{N})$ or 1.5 $\mathrm{Ueq}(\mathrm{C})$. After ten cycles of refinement, the final difference Fourier map showed peaks of no chemical significance.
The ORTEP and packing diagrams were generated using the software MERCURY [35].

\section{Supplementary information for XRD}

Crystallographic data for the compounds has been deposited with the Cambridge Crystallographic Data Centre as supplementary publication number CCDC 1845758. Copies of this information may be obtained free of charge via www.ccdc.cam.ac.uk/conts/retrieving.html (or from the CCDC, 12 Union Road, Cambridge CB2 1EZ, UK; fax: +441223-336033; e-mail: deposit@ccdc.cam.ac.uk).

Acknowledgements The authors acknowledge the services of $\mathrm{Dr}$ Pritesh Bhat and Vinod Devaraji, Application Scientist in molecular docking and molecular dynamic simulation studies using Schrodinger Software. The authors thank Dr. Suchetha Kumari Professor of Biochemistry, from K. S. Hedge Medical Academy (Nitte Deemed to be University) for her contribution in fatty acid study. The authors are grateful to Dr Vaishali Rai M Assistant Professor Department of Microbiology St. Aloysius College (Autonomous) Mangalore for his contribution in hemolysis assay. One of authors (Nadine Uwabagira) is also thankful to Indian Council for Culture Relations (ICCR) for granting scholarship.

\section{Compliance with ethical standards}

Conflict of interest We declare that there is no conflict of interest.

Human and animals rights No human or animal participant were involved in this study.

\section{References}

1. Ghasemi B, Sanjarani G, Sanjarani Z, Majidiani H (2015) Evaluation of anti-bacterial effects of some novel thiazole and imidazole derivatives against some pathogenic bacteria. Iran J Microbiol 5:281-286

2. Richard H, Charles $R$ (1996) Regulation of fatty acid and initiation by acyl acyl-carrier protein in E. coli. J Biol Chem 271:1833-1836

3. Peng-Cheng $L$, Kai-Rui W, Ying $Y$, Wen-Jun $M$, Jin $C$, Jing $X$, HaiLiang Z (2009) Design, synthesis and biological evaluation of novel thiazole derivatives as potent FabH inhibitors. Bioorg Med Chem Lett 19:6750-6754

4. Hayashi T, Yamamoto O, Sasaki H, Kawaguchi A, Okazaki H (1983) Mechanism of action of the antibiotic thiolactomycin inhibition of fatty acid synthesis of E. coli. Biochem Biophys Res Commun 115:1108-1113

5. Nishida I, Kawaguchi A, Yamada M (1984) Selective inhibition of type II fatty acid synthetase by the antibiotic thiolactomycin. Plant Cell Physiol 25:265-268

6. Tsay J, Charles R, Suzanna J (1992) Overproduction of $\beta$-ketoacylacyl carrier protein synthase. Iran J Bacteriol 174:508-513

7. Siddiqui N, Arshad F, Ahsan W, Alam S (2009) A valuable insight into the recent advances and biological activities. Int J Pharm Sci Drug Res 3:136-143 
8. Nayak SP, Narayana B, Sarojini BK, Hedge K, Shashidhara SK (2014) Design and synthesis of novel heterocyclic acetamide derivatives for potential analgesic, anti-inflammatory, and antimicrobial activities. Med Chem Res 23:4280-4294

9. Madni M, Hameed S, Ahmed N, Tahir N, Al-Masoudi A, Pannecouque $C$ (2017) Synthesis, in vitro a-glucosidase inhibitory activity and molecular docking studies of new thiazole derivatives. Med Chem Res 26:2653-2665

10. Garuti L, Roberti M, Pession A, Leoncini E, Hrelia S (2001) Synthesis and antiproliferative activity of some thiazolylbenzimidazole4,7-diones. Bioorg Med Chem Lett 11:3147-3149

11. Sadek B, Al-Tabakha M, Fahelelbom S (2011) Antimicrobial prospect of newly synthesized 1,3-thiazole derivatives. Molecules 16:9386-9396

12. Prakasha K, Raghavendra G, Harsha R, Channe D (2011) Design, synthesis and antimicrobial screening of amino acids conjugated 2-amino-4-arylthiazole derivatives. Int J Pharm Pharm Sci 3:120-125

13. Zhao $M$, Yin $Y$, Yu X, Sangani $C$, Wang $S$, Lu A, Yang L, Lv $P$, Jiang M, Zhu H (2015) Synthesis, biological evaluation and 3D-QSAR study of novel 4,5-dihydro-1 $\mathrm{H}$-pyrazole thiazole derivatives as BRAF $^{\mathrm{V} 600 \mathrm{E}}$ inhibitor. Bioorg Med Chem Lett 23:46-54

14. Praveen SA, Yathirajan SH, Narayana B, Sarojini BK (2014) Synthesis, characterization and antimicrobial studies of a few novel thiazole derivatives. Med Chem Res 23:259-268

15. Hargrave K, Hess F, Oliver J (1983) N-(4-Substituted-thiazolyl) oxamic acid derivatives, a new series of potent, orally active antiallergy agents. J Med Chem 26:1158-1163

16. Jaen J, Wise L, Caprathe B, Tecle H, Bergmeier S, Christine $H$, Humblet C, Heffner T, Meltzer L, Pugsley T (1990) 4(-1,2,5,6Tetrahydro-1-alkyl-3-pyridinyl-2 thiazolamines as novel class of compounds with central dopamine agonist properties. J Med Chem 33:311-317

17. Parrino B, Attanzio A, Spano V, Cascioferro S, Montarbano A, Barraja P, Tesoriere L, Diana P, Cirrincione G, Carbone A (2017) Synthesis, antitumor activity and CDK-1 inhibitor of new thiazole nortopsentin analogues. Eur J Med Chem 138:371-383

18. Zheng L, Qiu Q, Xu X, Wang X, Jiao L, Su X, Pan M, Huang W, Qian $H$ (2016) Design, synthesis and structure-activity relationship studies of new thiazole-based free fatty acid receptor 1 agonists for the treatment of type 2 diabetes. Eur J Med Chem 113:246-257

19. Mashima T, Seimiya H, Tsuruo T (2009) De novo fatty acid synthesis and related pathway as molecular targets for cancer therapy. Br J Cancer 100:1369-1372

20. Tsay J, Oh W, Larson T, Jackowski S, Rock S (1992) Isolation and characterization of the $\beta$-ketoacyl carrier protein synthase III gene FabH from E. coli K-12. J Biol Chem 10:6807-6814
21. Clough R, Matthis A, Barnum S, Jaworsk J (1992) Purification and characterization of $\beta$-ketoacyl acyl carrier protein synthase III from spinach. J Biol Chem 267:20992-20998

22. Richard H, Charles R (1996) Overproduction of $\beta$-ketoacyl-acyl carrier protein synthase I imparts thiolactomycin resistance to Escherichia coli K-12. J Biol Chem 271:1833-1836

23. Yavari I, Hossaini Z, Sabbaghan M, Ghazanfarpour DM (2009) A one-pot synthesis of functionalized thiazoles from acid chlorides, secondary amines, ethyl bromopyruvate, and ammonium thiocyanate. Mol Divers 13:295-300

24. Holla S, Malini V, Rao S, Sarojini BK, Kumari S (2003) Synthesis of some new 2,4-disubstituted thiazoles as possible antibacterial and anti-inflammatory agents. Eur J Med Chem 38:313-318

25. Huang W, Jia J, Edwards P, Dehesh K, Schneider G, Lindqvist $Y$ (1998) Crystal structure of $\beta$-ketoacyl-acyl carrier protein synthase II from $E$. coli reveals the molecular architecture of condensing enzymes. EMBO J 17:1183-1191

26. Davies C, Heath R, White S, Rock C (2000) The 1.8 A crystal structure and active-site architecture of $\beta$-ketoacyl-acyl carrier protein synthase III (FabH) from E. coli. Structure 8:185-195

27. Zhu L, Maruvada R, Sapirstein E, Malik KU, Golden M, Kum KS (2010) Arachidonic acid metabolism regulates E. coli penetration of the blood-brain barrier. Infect Immun 78:4302-4310

28. Elomaa E (1979) Enterotoxins of Escherichia coli and epilepsy. Med Hypotheses 5:707-710

29. Yurtta L, Özkay Y, Gencer HK (2015) Synthesis of new thiazole derivatives and their biological activity evaluation. J Chem 7:1-7

30. Balouiri M, Saddiqui M, Ibnsouda K (2016) Methods for in vitro evaluating antimicrobial activity; a review. J Pharm Anal 6:71-79

31. Sashidhara KV, Rao KB, Kushwara P, Modukuru RK, Singh $P$, Shukla PK, Chopra S, Pasupeleti M (2015) Novel chalcone-thiazole-hybrids as potent inhibitors of drug resistance Staphylococcus aureus. Med Chem Lett 6:809-813

32. Rigaku (2011) CrystalClear SM expert. Rigaku Corporation, Tokyo

33. Sheldrick GM (2008) A short history of SHLX. Acta Crystallogr A A64:112-122

34. Sheldrick GM (2015) SHLXT-integrated space-group and crystal structure determination. Acta Crystallogr C C71:3-8

35. Macrae C, Bruno I, Chisholm J, Edgington P, McCabe P, Pidcock E, Rodriguez L, Taylor R, Streek J, Wood P (2008) New features for visualization and investigation of crystal structures. J Appl Cryst 41:466-470

Publisher's Note Springer Nature remains neutral with regard to jurisdictional claims in published maps and institutional affiliations. 